\title{
Inequality in Japan (1892-1941): Physical stature, income, and health
}

\author{
Jean-Pascal Bassino ${ }^{\text {a,b,* }}$ \\ ${ }^{a}$ Department of Mathematics and Social Sciences, Paul Valéry University, Route de Mende, \\ 34000 Montpellier, France \\ ${ }^{\mathrm{b}}$ Institute of Economic Research, Hitotsubashi University, Naka 2-1, Kunitachi, \\ 186-8603 Tokyo, Japan
}

Received 16 October 2005; accepted 16 October 2005

\begin{abstract}
This paper investigates the relationship between physical stature, per capita income, health, and regional inequality in Japan at the prefecture-level for the period 1892-1941. The analysis shows that inequality in income and access to health services explains differences in average height of the population across the 47 Japanese prefectures during this period and that variation in income contributed to changes in height during the 1930s. Annual regional time series of height indicate that Japan experienced a regional convergence in biological welfare before 1914, and that a divergence occurred during the interwar period; personal inequality followed a similar pattern.
\end{abstract}

(C) 2005 Elsevier B.V. All rights reserved.

JEL classification: I1; I3; N3; N9; 01

Keywords: Physical stature; Height; Health; Inequality; Income distribution; Regional convergence; Japan

\section{Introduction}

How did industrialization and the emergence of a national market affect inequality, as measured by per capita income and indicators of biological welfare, during the initial stage of economic development in Japan? A number of studies have investigated the hypothesis of an inverted U-shaped curve of inequality (Kuznets, 1955) in pre-World War II Japan. Most of this work has focused on changes in income distribution among households at the national level.

\footnotetext{
* Tel.: +81 42580 8330; fax: +81 425808333

E-mail address: bassino@mfj.gr.jp.
} 
Various estimates of Gini coefficients suggest that personal inequality was on the rise in Japan before WWII (Minami, 1995). In contrast, relying on tax statistics, Moriguchi and Saez (2004) provide a measure of income concentration indicating that the share of higher income households remained fairly stable between 1885 and 1940.

A limitation of these studies is that they neglect changes in regional inequality. A stable personal income distribution at the national level can be the result of two different trends in regional and personal inequality. The first pattern is a convergence of regional average per capita income combined with amplification in the within-region dispersion of personal income in the most affluent regions. This is likely to happen in a country in which the residents of the poorest regions enjoy net gains from the process of national market integration and the highincome households of the rich regions receive a proportionally higher share of the additional revenues. The second possible pattern is a regional divergence combined with a contraction of personal income distribution in the most affluent regions. This interaction can also result in an absence of change in personal income distribution at the national level. Yet, in this second case, the poorest residents of the poorest regions are likely to lose out, at least in relative terms, while they win in the first scenario. Personal income distribution at the national level may appear identical in the two cases. However, the evolution in the gap between rich and poor regions and the evolution of within-region inequality among individuals are different, with obvious implications in terms of social welfare. ${ }^{1}$ Although it may be useful to investigate both personal and regional income distribution in parallel, this study focuses on regional inequality. $^{2}$

One of the most comprehensive studies on regional income inequality in the pre-World War II period remains that by Williamson (1965), which relies on estimates of per capita income for a number of countries. On the basis of this data, he identifies three phases in the evolution of income distribution: first, regional divergence; second, a plateau of high-level inequality; third, convergence. Barro and Sala-I-Martin (1992) analyze the Japanese case using regional per capita income figures for benchmark years from 1930 onward. They observe divergence between 1930 and 1940, and a convergence after $1950 .^{3}$ However, the trend prior to 1930 , during the initial phase of Japan's industrialization, which started in the late 19th century, is still largely uncharted territory. In the case of the U.S., Barro and Sala-I-Martin (1992) find a process of almost uninterrupted convergence from the 1880 s onward. The same trend is observed when using urban and rural real wages calculated for different years of the period 1850-1930 for 48 Spanish regions (Rosés and Sánchez-Alonso, 2004).

A convergence also occurred across nations in the Atlantic economy before 1913, during the first period of globalization, as a result of migration and trade (O'Rourke and Williamson, 1999). Williamson $(2000,2002)$ argues that Asian countries experienced a similar trend before 1913. The question remains, however, whether the reduction of transportation costs and the resulting market integration also led to a within-country regional convergence in Japan after the Meiji

\footnotetext{
${ }^{1}$ Bourguigon and Morrison (2002) analyze this issue at the global level in their study on inequality among world citizens.

${ }^{2}$ In this paper, the study is restricted to a measure of personal inequality in biological welfare at the national level. In principle, it would be possible to measure personal inequality at the regional level using the same height data. However, space constraints do not allow the analysis of the relation between regional and personal income distribution in detail in this paper.

3 They regard inter-regional migration as a key variable that might explain convergence. Interregional migration before 1940 is briefly discussed in Section 3.
} 
restoration. Time series of per capita income at the level of the 47 Japanese prefectures are available for only three benchmark years before WWII: 1930,1935 , and $1940 .{ }^{4}$ It is, however, possible to investigate changes in inequality by relying on indicators of biological welfare. In order to do so, annual regional series of the average height of Japanese conscripts for the period 1892-1941 are constructed. Using these data, it is then shown that height is a function of income and other variables such as health. It is therefore legitimate to use prefecture-level height time series for analyzing the patterns and determinants of regional and personal inequality in welfare.

The remainder of the paper is organized as follows. Section 2 briefly discusses the relationship between income, health, and stature, and the role played by other variables. Section 3 provides a description of the data (and data sources) used in the analysis; Section 4 examines the relationship between stature, per capita income, and health. Section 5 then uses regional time series of stature in order to analyze personal and regional convergence in welfare. Section 6 concludes.

\section{The relationship between stature, income, and health}

It is well known that income and stature are two complementary measures of welfare that do not necessarily evolve in parallel (Komlos, 1998). The reason is that stature is also influenced by other variables such as urbanization, food prices, and health conditions. A high degree of correlation between income and stature is observed in international comparisons of industrialized and developing countries in the second half of the 20th century (Steckel, 1995). ${ }^{5}$ The historical evidence is more varied, however. Heights tended to increase in developing countries in Europe, North America as well as in Japan in the late 19th and early 20th century regardless of the rate of industrialization. ${ }^{6}$ On the other hand, at the end of the 18th and first half of the 19th century heights tended to decline in the UK and USA, and a number of other countries while industrialization was proceeding at a reasonable pace (Margo and Steckel, 1983; Komlos, 1998). An international convergence in biological welfare and other non-income indicators of the standard of living occurred during the 20th century, particularly after WWII, while incomes diverged (Kenny, 2005).

Because time series analysis can lead to spurious results, it is preferable to analyze the link between stature, income, and health using cross sectional data in order to obtain more robust results. As remoteness can have a positive impact on stature, it appears appropriate to use regional data for a cross-sectional analysis. In doing so, we can also control for the possibility of an urban effect and other region-specific variables. Komlos $(1985,1989)$ indicates that, in preindustrial Europe, people were relatively tall in several less developed and mostly rural areas. ${ }^{7}$

\footnotetext{
${ }^{4}$ Although engaged in a war with China, Japan was not fully involved in WWII before 1941. The Japanese Navy was involved in WWI but suffered very few losses; the participation of the Army was almost symbolic (about $98 \%$ of the conscripts were in the Army and about $2 \%$ in the Navy). The Japanese economy was in expansion during WWI. Overall, it is likely that the impact of the conflict has been positive in terms of welfare.

${ }^{5}$ Using regional data of stature and per capita income, Meisel and Vega (2004) find that ethnicity plays an important role in Columbia. As regards Japan, the results presented in Sections 4 and 5 suggest that regional differences in the genetic pool are not a major factor.

${ }^{6}$ See Sandberg and Steckel (1997) on Sweden, Weir (1997) on France, and Shay (1994) and Honda (1997) on Japan. Baten (2001) provides additional evidence based on wage and stature data for 18th and 19th century Austria, Germany, France, The Netherlands, and Sweden.

${ }^{7}$ Komlos (1993) suggests that, around 1850, the population of Dalmatia was probably the tallest in Europe.
} 
One of the reasons why stature is positively correlated with distance to big cities is that, in the early industrial period, exposure to epidemic diseases was lower in remote areas. People living in remote areas may have been poorer but taller than the residents of large cities or of surrounding areas most exposed to diseases. Regional differences in the price of food relative to manufactured goods also played an important role at a time when transportation costs were high. ${ }^{8}$ Available information on Japanese regional prices suggests that a high degree of market integration was already achieved in the 18th century. Nevertheless, the decline of transportation costs in the late 19th century resulted in a reduced volatility of foodstuffs prices that certainly had a positive impact on nutritional status and welfare.

Average height is also positively affected by a number of other variables, including income, access to health services, and protein intake ${ }^{9}$; in contrast, uneven income distribution and exposure to diseases have a negative impact. Requirements related to labor, schooling, and other activities also influence body height. However, when comparing Japanese prefectures, it seems safe to assume that the average workload was similar across regions, as factor proportions and technology did not differ much. ${ }^{10}$

In the Japanese context of the late 19th and early 20th century, health appears to have been particularly important among the different variables influencing stature. The development of interregional trade, a modern transportation network, and temporary migration, facilitated the diffusion of disease from urban to rural areas. On the basis of a comparison of regional height data for the benchmark years 1896 and 1937, Shay (1994) argues that remoteness exerted a positive influence on height in Japan, as also shown by Komlos $(1985,1998)$ for Europe. ${ }^{11}$ In the late 19th century, the taller Japanese conscripts originated from regions of the northeastern and western peripheries. The conscripts from the rural prefectures in the north of Tokyo were among the shortest, which suggests that the urban penalty did apply to the surrounding countryside.

Although most scholars agree that the growth of food supply played a decisive role in the secular trend of growth in Japanese stature (Mosk and Pak, 1978; Mosk, 1996; Honda, 1997), estimates of food consumption for the Meiji period should be used with caution. For the late 19th century, the most accepted caloric intake figures (Mosk and Pak, 1978) are based on estimates of food supply (Shinohara, 1967) that are inconsistent with regional surveys of staple food consumption (Umemura et al., 1983). Thus, the accepted wisdom of a spectacular rise in per capita caloric intake during the Meiji period (1868-1912) ${ }^{12}$ may well be mistaken (Bassino, 2006). As suggested by Steckel (1999), the increase in protein intake may be more important than caloric intake. Stature grew markedly between the wars, a period of stagnation in per capita

\footnotetext{
${ }^{8}$ This is also observed in the case of the Tennessee region in the middle of the 19th century.

${ }^{9}$ Baten (2000) and Baten and Murray (2000) emphasize the importance of protein intake as an explanatory variable for regional differences in stature, particularly milk consumption in 18th and 19th century Bavaria. In the case of Japan, meat and milk did not play a major role in nutrition before the 1950s; pork consumption was traditional only in Kyushu and Okinawa. Soybeans, rice, and fish were still the major sources of protein in the interwar period (Tôyô Keizai, 1980, vol. 2, p. 590).

${ }^{10}$ As child labor has a negative impact on final stature, it would be useful to calculate school enrollment at the prefecture-level in order to estimate the average workload per child or youth. However, information on school dropout rates is unavailable. More importantly, we do not know whether the percentage of school children that also worked parttime was the same for all prefectures or how it fluctuated over time, especially during the 1930s.

${ }^{11}$ Shay (1994) also provides maps for these two benchmark years showing the average height by prefecture. As the ranking changed only gradually between 1892 and 1941, maps for other intermediate benchmark years would be quite similar. Thus, it appears preferable to focus on a quantitative analysis of the data.

${ }^{12}$ From about 1500 to 2200 calories per day between 1875 and 1912, according to Mosk and Pak (1978).
} 
caloric intake but of significant increases in animal protein intake. ${ }^{13}$ Unfortunately, we do not have per capita consumption data for the different kinds of foodstuffs at the regional level. Regional series of livestock, catches of fish, and soybeans output do not provide an acceptable proxy because animal products and beans were traded extensively. ${ }^{14}$

We should also take into account the difference between gross and net food intake, as only the latter really matters for human growth. In his study on the height of primary school students in Yamanashi prefecture, Saito (2003) underlines the importance of this distinction. He shows that students were shorter in areas where the exposure to diseases was highest, as morbidity increased the claims and thus reduced net consumption. ${ }^{15}$ This finding suggests that in spite of stagnation in the gross food supply, the net nutritional intake may well have been rising during the interwar period. In the pre-WWII Japanese context, health certainly played an important role. Mosk (1996) shows that improvements in the supply and quality of health services impacted significantly on the growth of human stature in sixteen industrial prefectures of Japan between 1926 and 1937. However, only a minority of Japanese had access to medical services on a regular basis before the mid-20th century.

As biological welfare depends on the interaction between the exposure to disease, which exerts a negative influence, and public health and medical inputs (PHM), which have a positive impact, it would be possible to investigate prefecture-level differences in these two variables. Mosk and Johannson (1986) and Johannson and Mosk (1987) show that age-adjusted death rates were high in high-income prefectures, corresponding to urban areas, in the period prior to the 1930s (although PHM per capita was correlated with average per capita income). By the 1930s, as a result of an increase in PHM, the correlation between high mortality and per capita income had disappeared, which suggests that there was no longer an urban penalty. However, it appears that there is no correlation between the prefecture-level average heights of conscripts in the 1930s or early 1940s and age-adjusted mortality rates in $1930 .{ }^{16}$ As stature is influenced by non-lethal diseases, and also to some extent by non-pathological exposures, mortality by itself is an insufficient proxy of biological welfare in the pre-WWII Japanese context. ${ }^{17}$

\section{Data}

Three types of data are used in this study: first, regional time series of average height, which is the dependant variable; second, various estimates of regional income for a number of benchmark

\footnotetext{
13 Average annual per capita consumption of meat increased only slightly in Japan between the early 1920s and the late $1930 \mathrm{~s}$, from 2.1 to $2.4 \mathrm{~kg}$; but the consumption of eggs rose from 1.5 to $2.2 \mathrm{~kg}$, that of milk from 2.1 to $3.8 \mathrm{~L}$, and that of fish from 8.1 to $12.7 \mathrm{~kg}$ (Tôyô Keizai, 1980, vol. 2, p. 590).

${ }^{14}$ As yearly weather variations impact on food crop output, it would be possible to examine indirect influence of climate upon variation in stature. Prefecture-level indicators of average daily temperatures, monthly rainfall, occurrence of typhoons, floods, and frost in springtime could be collected in order to investigate the role played by natural hazards (other than earthquakes); the major causes of rice crop failure were low summer temperatures in the north, and typhoons and floods in the south. Due to space limitations, the role of variations in weather is left for future research.

15 The influence of health conditions on stature in Asia before WWII is also discussed in Olds (2003), who examines the case of Taiwan under Japanese rule.

${ }^{16}$ Ministry of Health and Welfare, 1960. Standardized death rates by prefecture: 1930, 1950, 1955, and 1960. Institute of Population Problems, Research Series, No. 169.

${ }^{17}$ Data reported in Japanese statistical yearbooks could be used for constructing a composed index of exposure to disease and series of health and medical inputs in constant local currency. The researchers involved in the Cronos project (Keio University, Tokyo) are currently constructing such series at the prefecture-level.
} 
years; third, the number of midwives as a ratio of total population, which is used as an indicator of health care conditions at birth. ${ }^{18}$

Two sources for data on human stature in pre-WWII Japan are used: the first source is Army conscription reports, while the second is statistic collected by the Ministry of Education. In both sources, individual data are unavailable; the information is restricted to the number of individuals who fell into the different intervals of height at the time of physical examination, at age 20 in the case of conscripts. ${ }^{19}$ Average stature can be calculated from this information (Shay, 1994). For instance, in the report for the year 1941, the interval is of $5 \mathrm{~cm}$ with open tails below $140 \mathrm{~cm}$ and above $180 \mathrm{~cm} .{ }^{20}$ The percentage of the cohort in the two open tails is fairly small, between 4 and $5 \%$ before 1927 and less than $0.2 \%$ thereafter. Furthermore, the distribution of the population among the height intervals suggests that the data set is fairly dependable (Table 1). This pattern of normal distribution is observed for all prefectures and all years. The total number of conscripts increased from 348,015 in 1892 to 671,715 in $1941 .^{21}$ The comparison of the population data by age and the number of conscripts suggests that the coverage was close to $100 \% .^{22}$ Prefecturelevel data from conscription reports are available for the period 1892-1941. Data are missing for the years 1938-1940 in all archives consulted, ${ }^{23}$ presumably due to the destruction of most military archives by Japanese authorities at the end of WWII.

Other anthropometric data, recorded by the Ministry of Education, are available from 1900 onward (Mosk, 1996). These data include both male and female students, and covers a wide range of indicators for populations of different ages (from 8 to 20 years of age). However, the comparison between standing height of conscripts and male students of the same age indicates that the latter are biased, insofar older students were a tiny minority of male cohorts. Students aged 18 or 20 accounted for $2.0 \%$ in 1900 and $7.4 \%$ in $1935 .{ }^{24}$ It is likely that most of the students

\footnotetext{
${ }^{18}$ See Appendix A for further details on data sources for height and midwives. Regional-level time series are presented in a background paper, which is available upon request.

${ }^{19}$ Until 1935, the information is limited to body height; body weight at age 20 was also measured from 1926 onward.

20 The percentage of conscripts for which the information is reported as missing is extremely low $(0.7 \%$ in $1926,0.9 \%$ in 1927, 0.6\% in 1928-1932 and in 1941; no information on missing values is available for the other years during the observation period.

${ }^{21}$ Including 1630 conscripts from Karafuto (i.e. Southern Sakhalin), which became part of the USSR in 1945. There were only a few conscripts from Hokkaido before the second half of the 1890s (385 in 1893, 331 in 1894, and 391 in 1895; but 3951 in 1896 and increasing thereafter). When excluding the Hokkaido figures for 1893-1895, the smallest cohort is that of Toyama prefecture in 1895 (2723, which is surprisingly low compared with the figures for 1894 and 1896 , but the cohort of 1895 seems normally distributed among the height intervals). The largest cohorts were those of Tokyo, Osaka, and Hyogo prefectures (with a maximum of 38,174 for Tokyo in 1941).

22 The Japanese conscription system was established in 1873 by the Conscription Act (Chôhei Rei); for a discussion of the implementation and evolution of the system, see Kato (1996), Oe (1981), and Rokuhara (2005). From 1883, draft dodgers were subject to imprisonment for up to 1 year and a fine of 3-30 yen. Initially, it was possible to legally avoid the draft by moving abroad for study or paying for a substitute, or by becoming head or potential head of household (including through marriage or adoption). Legal opportunities for evasion were gradually restricted and, in 1889, illness and disability were made the sole criteria for exemption (Rokuhara, 2005, p. 86). Therefore, it is unlikely that a large number of individuals belonging to the cohort aged 20 escaped examination during the period 1892-1941 (corresponding to the data used in this paper). Smethurst (1974, pp. 159-160), in his description of the annual conscription physical examination during the interwar period, provides confirmation that the coverage was close to $100 \%$.

${ }^{23}$ Including those of the research center of the Self Defense Forces Agency (Japan's equivalent of a ministry of defense).

${ }^{24}$ The ratio of the number of students aged 18 and 20 to the total male population of the same age is calculated by relying on data reported in the CD-ROM "Historical Statistics of Japan (1868-1985)" published by the Japan Statistical Association (Tokyo, 1999). The total number of students is used as a proxy for male students; very few females had secondary and higher education before WWII.
} 
Table 1

Distribution of Japanese conscripts by height intervals in 1895, 1900, 1905, 1910, 1915, 1920, 1925, 1930, 1935, and 1941 (in \%)

\begin{tabular}{|c|c|c|c|c|c|c|c|c|c|c|}
\hline Height in $\mathrm{mm}$ & $>1697$ & $>1667$ & $>1636$ & $>1606$ & $>1576$ & $>1545$ & $>1515$ & $>1485$ & $>1454$ & $<1454$ \\
\hline 1895 & 1.1 & 2.7 & 7.0 & 13.2 & 19.6 & 19.6 & 17.2 & 10.5 & 5.2 & 4.0 \\
\hline 1900 & 1.3 & 3.2 & 7.9 & 14.3 & 20.1 & 20.5 & 16.0 & 9.4 & 4.3 & 3.0 \\
\hline 1905 & 1.6 & 3.7 & 8.7 & 15.5 & 20.7 & 20.5 & 15.0 & 8.2 & 3.8 & 2.3 \\
\hline 1910 & 2.1 & 4.4 & 9.6 & 16.5 & 20.9 & 19.7 & 14.2 & 7.6 & 3.3 & 1.9 \\
\hline 1915 & 2.3 & 4.8 & 10.3 & 16.8 & 21.0 & 19.3 & 13.6 & 7.2 & 3.0 & 1.7 \\
\hline 1920 & 2.9 & 5.6 & 11.5 & 17.9 & 21.1 & 18.7 & 12.4 & 6.1 & 2.5 & 1.2 \\
\hline 1925 & 3.6 & 6.5 & 12.7 & 18.9 & 21.2 & 17.8 & 11.2 & 5.3 & 2.0 & 0.9 \\
\hline Height in $\mathrm{mm}$ & $>1750$ & & & $>1650$ & $>1600$ & $>1550$ & & 00 & $>1450$ & $<1450$ \\
\hline 1930 & 0.5 & 3.4 & & 14.3 & 30.9 & 31.5 & 15 & & 3.6 & 0.7 \\
\hline 1935 & 0.7 & 4.1 & & 15.9 & 31.1 & 30.3 & 14 & & 3.2 & 0.6 \\
\hline 1941 & 0.8 & 5.0 & & 17.6 & 32.2 & 28.7 & 12 & & 2.6 & 0.5 \\
\hline
\end{tabular}

Sources: See Appendix A.

Table 2

Comparison of the average height of Japanese conscripts, Japanese students, and French and Italian conscripts in 1905, 1915,1925 , and 1935 (in mm)

\begin{tabular}{llllll}
\hline & $\begin{array}{l}\text { Japanese } \\
\text { conscripts } \\
\text { (at age 20) }\end{array}$ & $\begin{array}{l}\text { Japanese } \\
\text { students } \\
\text { (at age 18) }\end{array}$ & $\begin{array}{l}\text { Japanese } \\
\text { students } \\
\text { (at age 20) }\end{array}$ & $\begin{array}{l}\text { French } \\
\text { conscripts } \\
\text { (at age 20) }\end{array}$ & $\begin{array}{l}\text { Italian } \\
\text { conscripts } \\
\text { (at age 20) }\end{array}$ \\
\hline 1900 & 1564 & 1600 & 1609 & 1655 & 1638 \\
1910 & 1579 & 1600 & 1615 & 1661 & 1641 \\
1920 & 1588 & 1612 & 1624 & 1655 & 1647 \\
1930 & 1598 & 1618 & 1625 & 1674 & 1660 \\
\hline
\end{tabular}

Sources: See Appendix A for Japanese data; “Annuaire Statistique de la France”, various years, for French conscripts; Istituto Nazionale della Statistica, ISTAT (1958), “Sommario di Statistiche Storiche, 1861-1955”, for Italian conscripts.

were from a higher-income background. Hence, the students were much taller than the average population of the cohort (Table 2). ${ }^{25}$ The average height of Japanese students was as markedly different from that of Southern European conscripts. This finding suggests that the low stature of the Japanese was not primarily due to genetic factors. ${ }^{26}$ It seems that gender discrimination did

\footnotetext{
25 This means that the use of the data of the Ministry of Education for measuring the secular trend in the growth of physical stature, as for instance in Honda (1997, Fig. 7-4), is misleading. Average height data are upwardly biased and this induces an underestimation of the change that occurred before World War II.

${ }^{26}$ Considering that per capita income in Japan and in Europe have been as similar levels during the last decades, i.e., for at least a generation, one may be tempted to think that the lower average height of Japanese people is primarily due to differences in the genetic pools of these populations. Another possible explanation is that the Japanese are still catching up. Cole (2003) emphasizes that the rate of catching-up from one generation to the next is biologically constrained to avoid the cost of too rapid a catching-up process; therefore, reaching the full potential may take about six generations. Also, a number of factors such as differences in protein intake, exposure to stress, and physical exercise could also have resulted in a delay in the Japanese population. It is likely that the excessively short sleeping time of a large percentage of Japanese children and teenagers contributes to their lower stature when compared with Europeans of the same age (for surveys of average sleeping time of teenagers and young adults, see NHK (1990,2000)). Nevertheless, the secular upward trend in the stature of the Japanese is still observable in recent yearly data reported by the Ministry of Education.
} 
not have a great impact on access to food and other resources within the family in pre-WWII Japan (Honda, 1997). Thus, average male height can be regarded as an acceptable proxy for the biological welfare of the entire cohort of the same age.

Conscription data were not recorded for the resident population of each prefecture but for those whose family was registered in the prefecture. As a result of the Japanese family registration system (koseki), a number of young males (and females) born and raised in urban prefectures were not registered in the prefecture of birth or residence but, unless their parents had applied for registration in their prefecture of residence, in the prefecture of origin of the household (honseki). All males were therefore examined for conscription at age 20 in the prefecture of origin of their family. As a result, the size of the cohorts of the mostly rural prefectures includes a sizable number of urban residents of other prefectures.

The percentage of a population born outside the prefecture of residence enables us to estimate the magnitude of this discrepancy. Available data for 1920 and 1930 indicate that migrants and their dependants accounted for more than $10 \%$ of the resident population in 14 prefectures in 1920 and in 16 in 1930 (out of 47 prefectures), but for more than $20 \%$ in only 7 prefectures for the two benchmark years. These 7 prefectures correspond to the most important urbanized areas, plus the northern island of Hokkaido. ${ }^{27}$ Taeuber (1958) shows that in the most urbanized cities there was an important discrepancy between the resident population enumerated during the census undertaken in October 1920 and the population registered as having their household registration in these prefectures. The population registered in December 1918 as having honseki in the prefecture, as a share of the population enumerated during the census of October 1920, accounted for $65 \%$ in Tokyo Prefecture, $84 \%$ in Kanagawa, $99 \%$ in Aichi, $90 \%$ in Kyoto, $72 \%$ in Osaka, and $92 \%$ in Hyogo. ${ }^{28}$ As the population increased markedly in several of these prefectures between 1918 and $1920(+11 \%$ in Tokyo, $+6 \%$ in Kanagawa, $+6 \%$ in $\left.\mathrm{Hyogo}^{29}\right)$, the discrepancy is somewhat lower than suggested by the figures above. ${ }^{30}$

One way to cope with the problem of migration towards big cities is to introduce regional dummy variables in the quantitative analysis. It is safe to assume that in the most urbanized areas the income of most recent immigrants was much lower than the average of the prefectures of residence. Thus, internal migration does not prevent the investigation of the urban penalty. If an urban penalty is identified when relying upon conscription stature data, this may be regarded as an indication that this negative impact was actually even more severe.

Three kinds of prefecture-level indicators of per capita income are available. The first are estimates of per capita income of the resident population (kenmin shotoku) at current prices in

\footnotetext{
${ }^{27}$ The percentage was within a range of $20-30 \%$ for the prefectures comprising the urban areas of Yokohama, Kyoto, Kobe, and Fukuoka, and reached $40-50 \%$ for Tokyo and Osaka.

${ }^{28}$ Taeuber (1958, Table 8, 44).

${ }^{29}$ CD-ROM "Historical Statistics of Japan" of the Japan Statistical Association (1999). Available data for 1930 also show that the percentage of the resident population of big cities born outside the prefecture was smaller among those aged 15-19 than those aged 30-39 (Taeuber, 1958, Table 53, p. 152), suggesting that the average height of the conscripts may be an acceptable proxy for that of resident young males.

${ }^{30}$ An analysis based on average height data for macro-regions including the urban areas and the mostly rural neighboring prefectures does not solve the problem. In Tokyo, Kanagawa, and Osaka, only about one third of the immigrants originated from adjacent prefectures and barely half in Aichi, Kyoto, and Hyogo prefectures (Taeuber, 1958, Table 44, p. 128).
} 
1930, 1935, and $1940 .{ }^{31}$ These figures are converted at constant prices of 1934-36 by relying on the nation-wide GDE deflator ${ }^{32}$; the second are yearly estimates of regional output per agricultural household between 1930 and 1937, reconstructed by Obi and Nishikawa (1961), while the third are estimates of per capita assets in 1905 (Igarashi and Takahashi, 1906). In this latter source, assets are defined as the market value of land, construction, and financial assets. Considering the high share of land in the total assets in most prefectures, with the main exception of Tokyo and Osaka, it seems acceptable to assume that regional differences in the productivity of the total stock of assets were small. At the individual level, the distribution of assets was certainly more unequal than that of income but the data are prefecture-level average stock of assets per capita. Therefore, these figures can be used as indicators of regional differences in average per capita income.

The nutrition survey of commoners in 1886, reported in Umemura et al. (1983, pp. 33-49), is used as an indicator of differences in regional per capita income in the late 19th century. This survey provides regional data for the share of rice, barley, other cereals, buckwheat, and potatoes (Irish and sweet potatoes) in total staple food intake. There is no information regarding the supply of other food items that are sources of protein other than staple foods (cereals and buckwheat accounted for a major share of protein intake in pre-WWII Japan). Considering that rice was the preferred staple food, and the most expensive in terms of unit price per calorie, the share of rice in total staple food consumption can be used as an indicator of regional inequality. ${ }^{33}$

Regional differences in access to health services are measured by relying on the ratio of midwives to total population of the number. The number of midwives is reported in the statistical

\footnotetext{
${ }^{31}$ Reconstructed by the Economic Planning Agency (EPA) for 46 of the 47 prefectures (quoted in Toyo Keizai, 1980, vol. 1, p. 115. The original data source is Keizai Kikakuchô [Economic Planning Agency, EPA], Chiiki mondai kenkyû chôsa shitsu (1964), “Chiiki kankei tôkei yôran”, pp. 114, 137-139). The EPA did not calculate per capita income for Okinawa because this prefecture was not part of Japan but under US administration at the time of the estimation. Tominaga (2003) provides estimates of per capita income in Okinawa for the same years.

32 (Ohkawa and Shinohara, 1979, p. 387); regional differences in the variation of the CPI and other components of regional GDE deflators are neglected for want of available information. Details on the estimation procedure of prefecturelevel per capita income are not available, but considering that all existing estimates of per capita GDP or GDE use Tokyo prices, it is likely that the same price series were used for calculating regional incomes. Local price data are not available for the all prefectures. The figures for ten prefectures reported in various issues of the yearbook of the publishing company Daiamondo (Diamond) during the 1930s show that regional differences in the Consumer Price Index are in the range of $10 \%$ of the Tokyo price index.

${ }^{33}$ Cultural preferences were broadly similar across Japan; thus, it is likely that the income elasticity of demand for the different types of foodstuffs was at comparable levels all over the country. For the interwar period, average per capita intake data by income group (Rôdô Undô Shiryô Iinkai, 1959, p. 568) suggest that the income elasticity of demand was not very high and in the same range for rice and most other foodstuffs. Accordingly, regional inequality in the quality of nutritional intake, particularly protein intake, should be regarded as correlated with regional differences in per capita income. Considering the income elasticity of demand for rice, the fact that in a given prefecture rural households were able to consume a high proportion of rice as a percentage of staple food intake suggests that their revenue also allowed them to consume a larger quantity of animal protein. Rice accounted for about half of staple food consumption in 1886 , though there were large regional differences: the maximum was $83 \%$ in Toyama prefecture and the minimum $19 \%$ in Kumamoto prefecture. Apart from the implication in terms of per capita income, a high share of rice in staple food consumption may also have a direct impact on stature. The higher content in essential amino acid proteins makes rice a much more balanced source of nutriments than most other cereals. For a non-technical discussion on rice as a high quality staple food, see (Ishige, 2000, pp. 19-20). It should be noted that buckwheat, which played an important role in the food supply of several mountainous areas of Japan, is also significantly superior to barley, wheat, and maize as a source of proteins (Mazza, 2000, pp. 92-93).
} 
reports of the Ministry of Interior published between 1884 and $1935,{ }^{34}$ appears a much better indicator of the overall quality of local health systems than the number of physicians, dentists, nurses, or pharmacists, and the number of hospital beds. ${ }^{35}$ The presence of a midwife at the time of delivery is an important determinant of health conditions for both the newborn and the mother. Her intervention reduces the stress related to delivery and the risk of poor health at young age that may result from postpartum illness or death of the mother. The traditional medicines that were customarily administered by midwives impacted on postpartum physical conditions of the mother, preventing anemia and enhancing lactation (Ushiroyama et al., 2003). As the interval between births was short before WWII, the improvement of mothers' postpartum health conditions had a positive influence on siblings as it reduced the risk of hiring out child labor to compensate for the loss of the mother's income.

\section{The relation of stature to per capita income and health in pre-World War II Japan}

This section uses cross-section OLS regressions to analyze, at the regional level, the relationship between height and the different indicators of per capita income. In the first part of this section, the relationship is tested in semi-log form, following the same approach as Steckel (1995). ${ }^{36}$ The major difference is that right side lags are introduced. A 20-year lag is used for midwives because their role at the time of birth is critical. Because income data are available at the prefecture-level for 1930, 1935, and 1940, the maximum lag that could be used is 11 years between incomes in 1930 versus height in 1941. Moreover, a 6-year lag between incomes in 1930 and 1935 versus heights in 1936 and 1941, respectively, was also tried. Shorter lags are also possible. We also estimated the relationship without a lag for 1930 and 1935, and a 1-year lag for 1940. Sample size therefore ranges from 47 to $141 .{ }^{37}$ On the other hand, with the 11-year lag, the sample size is only 47 . The distance to big cities is also introduced as an independent variable along with a number of regional dummy variables in an attempt to capture the determinants of biological welfare such as exposure to pathogens, nutritional status, and differences in workload that cannot be observed directly. For per capita income, the relationship investigated can be represented by the following equation:

$$
\begin{aligned}
& H_{i t}=\alpha+\beta_{1} \log Y_{i, t-A}+\beta_{2} \log M_{i, t-B}+\beta_{3} \log \mathrm{DBC}_{i}+\gamma_{1} D_{T}+\gamma_{2} D_{U} \\
& \quad+\gamma_{3} D r_{i}+\gamma_{4} D_{\mathrm{Silk}}+\varepsilon
\end{aligned}
$$

\footnotetext{
${ }^{34}$ Sato (1997) and Sawayama (1998) offer a discussion on the role of midwives in the Japanese health system in preWWII Japan.

${ }^{35}$ For many Japanese, the opportunity to visit a physician was restricted to the issuance of a death certificate for a deceased household member (mandatory since the early Meiji period). The number of midwives, which is reported in the statistical reports of the Ministry of Interior published between 1884 and 1935, may be a better indicator of the overall quality of local health systems than the number of physicians, dentists, nurses, or pharmacists, and the number of hospital beds used by Mosk (1996, p. 111) for constructing an index of access to public health and medical services.

${ }^{36}$ An alternative approach, suggested by Brinkman et al., (1988), would be to consider body height as the result of a cumulative process based on changes in the level of income during the first 20 years of life. However, using this approach would not be practicable here because annual per capita income data at the prefecture-level to construct yearly time series data are not available. Moreover, the approach has some shortcomings, as shown by Mandemakers and van Zanden (1993).

37 Judging from the impact of the deterioration in living standards upon the stature of conscripts, for instance in France at the end of WWI (data are reported in Annuaire Statistique de la France), it seems reasonable to expect that the lag would be closer to 6 than to 11 years, and indeed the results of the tests are better with a 6 -year lag.
} 
where $H_{i t}$ is the average height in prefecture $i$ (in $\mathrm{mm}$ ) in year $t, Y_{i, t-A}$ is real per capita income (in constant yen of 1934-36) in year $t-A$, and $M_{i, t-B}$ is the log number of midwives per 100,000 habitants in year $t-B .^{38} \mathrm{DBC}_{i}$ is the distance in kilometers between the geographic center of prefecture $i$ and the closest big city (Tokyo, Nagoya, Osaka, Kyoto, Kobe, or Fukuoka); $D_{y}$ is a year dummy variable introduced in the equation in the variant using pooled cross-sections. $D_{U}$ is a dummy variable to capture the urban penalty (or urban premium) for the five prefectures comprising the biggest industrial cities (Tokyo, Nagoya, Kyoto, Osaka, and Kobe). ${ }^{39} \mathrm{Dr}_{i}$ is a dummy variable for the different regions, which are: Tohoku, Kanto, Hokuriku, Tokai, Tosan, Kinki, Chugoku, Shikoku, Kyushu, along with Hokkaido, and Okinawa. ${ }^{40}$ A dummy $D_{\text {Silk }}$ is introduced to capture the fixed effect of silk production, which was concentrated in the prefectures of Fukushima, Gumma, Nagano, Saitama, and Yamanashi. In these prefectures, labor inputs required by sericulture put a proportionally heavier burden on women, with a probable negative impact on the conditions of women during pregnancy, the care of children, and consequently the final stature at adult age. Also, the commercialization of cocoons involved numerous traders coming from urban areas and therefore increased the risk of exposure to disease of a large share of the rural population.

The relationship between income and stature is also measured by relying on the other two indicators of the standard of living: income per agricultural household (AGY) and the stock of assets per capita $(A)$. Again, 6- and 11-year lags are used, while the number of midwives is taken into account with a 20-year lag, as in Eq. (1). The estimated equations are as follows:

$$
\begin{aligned}
H_{i t}= & \alpha+\beta_{1} \log \mathrm{AGY}_{i, t-A}+\beta_{2} \log M_{i, t-B}+\beta_{3} \log \mathrm{DBC}_{i}+\gamma_{1} D_{T}+\gamma_{2} D_{U}+\gamma_{3} \mathrm{Dr}_{i} \\
& +\gamma_{4} D_{\mathrm{Silk}}+\varepsilon \\
H_{i t}= & \alpha+\beta_{1} \log A_{i, t-A}+\beta_{2} \log M_{i, t-B}+\beta_{3} \log \mathrm{DBC}_{i}+\gamma_{1} D_{U}+\gamma_{2} \mathrm{Dr}_{i}+\gamma_{3} D_{\text {Silk }}+\varepsilon
\end{aligned}
$$

The estimation results show that stature is positively correlated cross-sectionally with per capita GDP in pre-WWII Japan (Table 3). The coefficients for income are comparable to those obtained by Saito (2004), in $\log -\log$ form, in his study based on individual data for a village of Northern Japan in the interwar period. The relationship between body height and the two other indicators of living standards is also positive and significant (Tables 4 and 5). The coefficient of the number of midwives is positive and significant, as expected. But in the case of Eq. (2), the coefficient for agricultural income then is no longer significant (Table 4). The significant and negative coefficient for the distance to big cities observed in Eqs. (1a), (1b), and (2) indicates a rural penalty that may be related to lower public health expenditures in the most remote areas.

The negative and significant coefficient obtained for the urban dummy when per capita income is the explanatory variable; Eq. (1a) and (1b) indicate an urban penalty. When

\footnotetext{
38 See notes of Table 3 .

39 Aichi prefecture for Nagoya, and Hyogo prefecture for Kobe.

${ }^{40}$ See Appendix B for a list of prefectures for each macro-region. The rationale for including regional dummies is that, within each macro-region, the prefectures were rather similar in terms of climate, agricultural techniques, food consumption, patterns, and opportunities for part-time job during the agricultural slack season.
} 
Table 3

Relationship of stature (in $\mathrm{cm}$ ) to per capita income and the number of midwives at the prefecture-level (OLS, semi-log; dependent variable: average stature)

\begin{tabular}{|c|c|c|c|c|c|}
\hline & Model 1 & Model 2 & Model 3 & Model 4 & Model 5 \\
\hline \multicolumn{6}{|l|}{ Eq. (1a) } \\
\hline Constant & $153.65^{*}$ & $151.93^{*}$ & $151.31^{*}$ & $154.28^{*}$ & $156.30^{*}$ \\
\hline $\log Y_{t-6}$ & $1.81^{*}$ & $3.16^{*}$ & $3.01^{*}$ & $1.74^{*}$ & $1.08^{*}$ \\
\hline $\log M_{t-20}$ & $1.67^{*}$ & $1.68^{*}$ & $1.69^{*}$ & $1.42^{*}$ & $0.99^{*}$ \\
\hline$D_{t}$ & $0.47^{*}$ & $0.45^{*}$ & $0.43^{*}$ & $0.48^{*}$ & $0.51^{*}$ \\
\hline $\log \mathrm{DBC}$ & & $-0.42^{* *}$ & & & \\
\hline$D_{\text {Urban }}$ & & & $-1.18^{*}$ & & \\
\hline$D_{\text {Silk }}$ & & & & $-0.44^{* * *}$ & \\
\hline$D_{\text {Tohoku }}$ & & & & & $-0.39^{* *}$ \\
\hline$D_{\text {Kanto }}$ & & & & & $-0.56^{*}$ \\
\hline$D_{\text {Kinki }}$ & & & & & $0.83^{*}$ \\
\hline$D_{\text {Chugoku }}$ & & & & & $0.76^{*}$ \\
\hline$D_{\text {Okinawa }}$ & & & & & $-2.40^{*}$ \\
\hline Adjusted $R^{2}$ & 0.49 & 0.52 & 0.55 & 0.55 & 0.79 \\
\hline$N$ & 94 & 84 & 94 & 94 & 94 \\
\hline \multicolumn{6}{|l|}{ Eq. (1b) } \\
\hline Constant & $153.64^{*}$ & $149.95^{*}$ & $150.44^{*}$ & $154.26^{*}$ & $156.39^{*}$ \\
\hline $\log Y_{t-11}$ & $1.89^{*}$ & $4.43^{*}$ & $3.60^{*}$ & $1.84^{*}$ & $1.04^{* *}$ \\
\hline $\log M_{t-20}$ & $1.87^{*}$ & $1.72^{*}$ & $1.81^{*}$ & $1.62^{* *}$ & $1.30^{*}$ \\
\hline $\log \mathrm{DBC}$ & & $-0.45^{*}$ & & & \\
\hline$D_{\text {Urban }}$ & & & $-1.46^{* *}$ & & \\
\hline$D_{\text {Silk }}$ & & & & -0.47 & \\
\hline$D_{\text {Tohoku }}$ & & & & & $-0.59^{* *}$ \\
\hline$D_{\text {Kanto }}$ & & & & & $-0.56^{*}$ \\
\hline$D_{\text {Kinki }}$ & & & & & $0.80^{*}$ \\
\hline$D_{\text {Chugoku }}$ & & & & & $0.87^{*}$ \\
\hline$D_{\text {Okinawa }}$ & & & & & $-1.83^{*}$ \\
\hline Adjusted $R^{2}$ & 0.46 & 0.54 & 0.55 & 0.47 & 0.77 \\
\hline$N$ & 47 & 40 & 47 & 47 & 47 \\
\hline \multicolumn{6}{|l|}{ Eq. (1c) } \\
\hline Constant & $154.32^{*}$ & $153.53^{*}$ & $153.00^{*}$ & $154.93^{*}$ & $156.44^{*}$ \\
\hline $\log Y_{t-1}$ & $1.60^{*}$ & $2.47^{*}$ & $2.25^{*}$ & $1.53^{*}$ & $1.32^{*}$ \\
\hline $\log M_{t-20}$ & $1.41^{*}$ & $1.44^{*}$ & $1.44^{*}$ & $1.15^{*}$ & $0.82^{*}$ \\
\hline$D_{t}$ & $0.67^{*}$ & $0.65^{*}$ & $0.65^{*}$ & $0.70^{*}$ & $0.74^{*}$ \\
\hline$D_{t-5}$ & 0.16 & 0.13 & 0.14 & 0.18 & $0.20^{* * *}$ \\
\hline $\log \mathrm{DBC}$ & & $-0.43^{* *}$ & & & \\
\hline$D_{\text {Urban }}$ & & & $-0.66^{* *}$ & & \\
\hline$D_{\text {Silk }}$ & & & & $-0.44^{* *}$ & \\
\hline$D_{\text {Tohoku }}$ & & & & & $-0.77^{*}$ \\
\hline$D_{\text {Kanto }}$ & & & & & $-1.13^{*}$ \\
\hline$D_{\text {Hokuriku }}$ & & & & & $-0.86^{*}$ \\
\hline$D_{\text {Tosan }}$ & & & & & $-0.73^{*}$ \\
\hline$D_{\text {Tokai }}$ & & & & & $-0.75^{*}$ \\
\hline$D_{\text {Kyushu }}$ & & & & & $-0.46^{*}$ \\
\hline$D_{\text {Okinawa }}$ & & & & & $-3.32^{*}$ \\
\hline Adjusted $R^{2}$ & 0.45 & 0.45 & 0.47 & 0.50 & 0.78 \\
\hline$N$ & 141 & 120 & 141 & 141 & 141 \\
\hline
\end{tabular}


Table 3 (Continued)

\begin{tabular}{|c|c|c|c|c|c|}
\hline & Model 1 & Model 2 & Model 3 & Model 4 & Model 5 \\
\hline \multicolumn{6}{|l|}{ Eq. (1d) } \\
\hline Constant & $154.56^{*}$ & $154.47^{*}$ & $153.54^{*}$ & $155.10^{*}$ & $156.67^{*}$ \\
\hline $\log Y_{t}$ & $1.84^{*}$ & $2.51^{*}$ & $2.37^{*}$ & $1.78^{*}$ & $1.37^{*}$ \\
\hline $\log M_{t-20}$ & $0.88^{* * * *}$ & $0.93^{* * *}$ & $0.88^{* * * *}$ & 0.65 & $0.53^{* * *}$ \\
\hline$D_{t}$ & $0.34^{* * * *}$ & 0.30 & $0.32^{* * * * *}$ & $0.35^{* *}$ & $0.37^{*}$ \\
\hline $\log \mathrm{DBC}$ & & $-0.58^{* *}$ & & & \\
\hline$D_{\text {Urban }}$ & & & -0.49 & & \\
\hline$D_{\text {Silk }}$ & & & & -0.36 & \\
\hline$D_{\text {Tohoku }}$ & & & & & $-0.61^{*}$ \\
\hline$D_{\text {Kanto }}$ & & & & & $-1.09^{*}$ \\
\hline$D_{\text {Hokuriku }}$ & & & & & $-0.88^{*}$ \\
\hline$D_{\text {Tosan }}$ & & & & & $-0.66^{* *}$ \\
\hline$D_{\text {Tokai }}$ & & & & & $-0.65^{* *}$ \\
\hline$D_{\text {Kyushu }}$ & & & & & $-0.46^{* *}$ \\
\hline$D_{\text {Okinawa }}$ & & & & & $-4.59^{*}$ \\
\hline Adjusted $R^{2}$ & 0.29 & 0.28 & 0.30 & 0.29 & 0.78 \\
\hline$N$ & 94 & 80 & 94 & 94 & 94 \\
\hline
\end{tabular}

Notes: Variables with non-significant coefficients have been dropped. Silk is not significant when included in the equation along with DUrban (urban dummy is for 5 prefectures; see text) or with the variable DBC (distance to big cities).

Eq. (1a): Pooled cross-section; dependent variable is stature in 1941 and 1936.

Eq. (1b): Dependent variable is stature in 1941.

Eq. (1c): Pooled cross-section; dependent variable is stature in 1941, 1936, and 1931.

Eq. (1d): Pooled cross-section; dependent variable is stature in 1935 and 1930.

Denotes coefficients significant at the $1 \%$ level.

** Denotes coefficients significant at the $5 \%$ level.

*** Denotes coefficients significant at the $10 \%$ level.

Table 4

Relationship of stature (in $\mathrm{cm}$ ) to income per agricultural household and the number of midwives at the prefecture-level (OLS, semi-log; pooled cross section; dependent variable: average stature in 1941 and 1936)

\begin{tabular}{|c|c|c|c|c|c|}
\hline Eq. (2) & Model 1 & Model 2 & Model 3 & Model 4 & Model 5 \\
\hline Constant & $154.48^{*}$ & $153.68^{*}$ & $157.94^{*}$ & $155.03^{*}$ & $155.52^{*}$ \\
\hline $\log \mathrm{AGY}_{t-6}$ & $2.87^{*}$ & 1.18 & 0.69 & 1.16 & 0.93 \\
\hline $\log M_{t-20}$ & & $2.43^{*}$ & $1.42^{*}$ & $1.63^{*}$ & $1.60^{*}$ \\
\hline$D_{t}$ & $0.59^{*}$ & $0.50^{*}$ & $0.53^{*}$ & $0.53^{*}$ & $0.53^{*}$ \\
\hline $\log \mathrm{DBC}$ & & & $-0.70^{*}$ & & \\
\hline$D_{\text {Urban }}$ & & & & $0.50^{*}$ & \\
\hline$D_{\text {Silk }}$ & & & $-0.78^{*}$ & $-0.67^{* *}$ & \\
\hline$D_{\text {Tohoku }}$ & & & & & $-0.59^{*}$ \\
\hline$D_{\text {Kanto }}$ & & & 0.42 & 0.42 & $-0.41^{*}$ \\
\hline$D_{\text {Kinki }}$ & & & 80 & 94 & $1.10^{*}$ \\
\hline$D_{\text {Chugoku }}$ & & & & & $0.97^{*}$ \\
\hline$D_{\text {Shikoku }}$ & & & & & $0.33^{*}$ \\
\hline$D_{\text {Okinawa }}$ & & & & & $-1.96^{*}$ \\
\hline Adjusted $R^{2}$ & 0.14 & 0.36 & 0.42 & 0.42 & 0.76 \\
\hline$N$ & 94 & 94 & 80 & 94 & 94 \\
\hline
\end{tabular}

Notes: Results are similar with an 11-year lag, though the $R$-squared values are lower. The urban dummy is for 12 prefectures (see text). Variables with non-significant coefficients have been dropped.

* Denotes coefficients significant at the $1 \%$ level.

** Denotes coefficients significant at the 5\% level. 
Table 5

Relationship of stature (in $\mathrm{cm}$ ) to per capita assets and the number of midwives at the prefecture-level (OLS, semi-log; dependent variable: average stature in 1911)

\begin{tabular}{lccc}
\hline Eq. (3) & (a) & (b) & (c) \\
\hline Constant & $139.87^{*}$ & $139.69^{*}$ & $139.44^{*}$ \\
$\log A_{t-6}$ & $3.70^{*}$ & $3.80^{*}$ & $4.09^{*}$ \\
$\log M_{t-20}$ & $0.54^{*}$ & 0.38 & -0.09 \\
$D_{\text {Silk }}$ & & $-0.57^{*}$ & $-1.05^{*}$ \\
$D_{\text {Kanto }}$ & 0.38 & & $-0.72^{* * *}$ \\
$D_{\text {Hokuriku }}$ & 47 & 47 & $-0.70^{* * *}$ \\
$D_{\text {Tosan }}$ & & & $-1.84^{* *}$ \\
$D_{\text {Okinawa }}$ & 0.38 & 0.40 & 0.57 \\
Adjusted $R^{2}$ & 47 & 47 & 47 \\
$N$ & 47 \\
\hline
\end{tabular}

Notes: The coefficients for urban dummies and DBC are not significant; results are similar with an 11-year lag, though the $R$-squared values are lower. Variables with non-significant coefficients have been dropped.

* Denotes coefficients significant at the $1 \%$ level.

** Denotes coefficients significant at the $5 \%$ level.

*** Denotes coefficients significant at the $10 \%$ level.

agricultural income is used (Eq. (2)), the coefficient for the urban dummy is positive. ${ }^{41} \mathrm{~A}$ significant coefficient is obtained for the silk dummy, as expected with a negative sign. The results observed using income data for the 1930s may reflect the sharp decline in silk prices and output resulting from the fall of American demand for Japanese silk during the Great Depression. But the results obtained using pre-WWI data support the hypothesis of a negative impact on biological welfare caused by the heavy workload of women, and possibly by the additional exposure to disease brought by the domestic trade in cocoons. Regional dummies improve the adjusted $R$-squared, particularly in Eqs. (1) and (2), suggesting regional patterns that may be related to differences in income and wealth distribution at the regional level, but the relation is robust to the exclusion of the dummies. If per capita income is used as an explanatory variable (Eq. (1a) and (1b)), a negative coefficient is observed for the Tohoku and Kanto regions (respectively, the northeast of Japan and the area around Tokyo) and a positive one for the Kinki and Chugoku regions (respectively, the area around Kyoto, Osaka, and Kobe, and the area around Hiroshima and Okayama). These results may reflect the higher level of crop diversification as well as the greater opportunities for occasional or part-time non-agricultural jobs in Eastern Japan that contributed to reduce the prevalence of absolute poverty. A significant, negative and relatively large coefficient is obtained for the regional dummy variable Okinawa, which may be due to the high incidence of tropical diseases. ${ }^{42}$

\footnotetext{
${ }^{41}$ In Eq. (2), the specification of the urban dummy is different from that used in Eq. (1). The aim is to capture the influence of the closeness of urban markets upon agricultural income. Twelve prefectures are selected: Tokyo and the three neighboring prefectures of Chiba, Saitama, and Kanagawa, along with Aichi, Kyoto, Osaka, Hyogo, Okayama, Hiroshima, Fukuoka, and Nagasaki.

${ }^{42}$ Shay (1994) suggests that the low average height in Okinawa may be due to genetic differences. According to estimates by Tominaga (2003), per capita income in this prefecture was one of the lowest in Japan before WWII, and it has remained so until this day. A higher incidence of malaria and other tropical diseases may explain why average stature in Okinawa was much lower than in the rest of the country. See Dunn (1993) for a discussion of malaria-induced anemia.
} 
Table 6

Relationship of stature to the share of rice and other items in staple food consumption (OLS, semi-log; dependent variable: average stature)

\begin{tabular}{lccr}
\hline Eq. (4) & (a) & (b) & (c) \\
\hline Constant & $1506.13^{*}$ & $1530.80^{*}$ & $1528.11^{*}$ \\
$\log$ Rice & $31.08^{*}$ & $16.39^{* *}$ & $25.79^{* * *}$ \\
$\log$ SweetPotatoes & $6.16^{* * *}$ & & $7.08^{* * *}$ \\
$\log$ DBC & & & $-7.59^{* *}$ \\
$D_{\text {Tohoku }}$ & & $11.84^{* * *}$ & $13.59^{* * *}$ \\
$D_{\text {Chugoku }}$ & & $6.24^{* * *}$ & $5.90^{* * *}$ \\
$D_{\text {Kyushu }}$ & & $6.82^{* *}$ & \\
Adjusted $R^{2}$ & 0.16 & 0.31 & 0.30 \\
Observations & 38 & 45 & 33 \\
\hline
\end{tabular}

Regional dummy variables with non-significant coefficients have been dropped.

* Denotes coefficients significant at the $1 \%$ level.

** Denotes coefficients significant at the $5 \%$ level.

**** Denotes coefficients significant at the $10 \%$ level.

Relying on the share of rice and other items in staple food consumption as a proxy for income inequality, Eq. (4) estimates the relationship between height and the standard of living in the late 19 th century.

$$
H_{i t}=\alpha+\beta_{1} \mathrm{Nr}_{i(t-a)}+\beta_{2} \mathrm{Ns}_{i(t-a)}+\beta_{3} \mathrm{Nb}_{i(t-a)}+\beta_{4} \mathrm{Nm}_{i(t-a)}+\gamma_{1} \mathrm{DBC}_{i}+\gamma_{2} \mathrm{Dr}_{i}+\varepsilon
$$

$\mathrm{Nr}$ is the log of the share of rice in total staple food consumption. Similarly, Ns stands for the share of sweet potatoes, $\mathrm{Nb}$ for barley, and $\mathrm{Nm}$ for miscellaneous cereals. The same regional dummy variables and the variable for the distance to big cities are also introduced. A 6-year lag between the dependent variable and the indicators of nutrition is used. Available food consumption data are for 1886 and the earliest prefecture-level stature data figures are for the year 1892. Given that the shares of the different staples in food consumption were fairly stable between the 1860 s and the 1880 s, it is unlikely that major changes occurred between the mid1880 s and the early 1890 s. As prefecture level data on the number of midwives are available only from 1884 onward, this variable is not introduced in the analysis.

The estimation results for Eq. (4) are presented in Table 6. As expected, a significant and positive coefficient is obtained for rice. A significant positive coefficient is also obtained for sweet potatoes. Positive and significant coefficients are obtained for the regional dummies for two of the major areas of cultivation of sweet potatoes, Kyushu and Chugoku, when the variable for the share of sweet potatoes is omitted. Sweet potatoes were used both as a staple for human alimentation and as feed for animal husbandry. As part of the output was not suitable for human consumption, a surplus of sweet potatoes in excess of human consumption allowed increasing the production of meat and eggs, which is likely to have had a positive and significant impact on human stature. The negative coefficient for the distance to big cities suggests the existence of a penalty for remoteness in the late 19th century, once differences in quality of nutrition (and therefore presumably income) are controlled for.

The second part of this section analyzes the sensitivity of height to changes in per capita income at the prefecture level, both with and without lags. This elasticity is measured as the rate of growth of the log for both height and real per capita income (Eq. (5)).

$$
\Delta \log H_{i(t, t-a)}=\alpha+\beta \Delta \log Y_{i(t-b, t-c)}+\gamma_{1} D_{t}+\gamma_{2} \operatorname{Dr}_{i}+\varepsilon
$$


Table 7

Sensitivity of human growth to variations in per capita income (OLS, log-log; dependent variable: variation of average stature)

\begin{tabular}{lcc}
\hline Eq. $(5)$ & Pooled cross-section regression & Cross-section \\
\hline Constant & $0.00073^{*}$ & $0.00231^{*}$ \\
$\Delta \log Y_{(t-a ; t-a-5)}$ & $0.00214^{*}$ & $0.00242^{* *}$ \\
$\Delta \log Y_{(t-a ; t-a-10)}$ & & \\
$D_{t}$ & $0.00086^{*}$ & $-0.00075^{* *}$ \\
$D_{\text {Tohoku }}$ & $-0.00039^{* *}$ & $0.00133^{* * *}$ \\
$D_{\text {Okinawa }}$ & $0.00069^{* *}$ & 0.401 \\
Adjusted $R^{2}$ & 0.49 & 47 \\
Observations & 94 & \\
\hline
\end{tabular}

Notes: (a) Dependent variable: variation in height in 1936-41 and 1931-36, with $a=1$. (b) Dependent variable: height: variation in height in1931-41, with $a=1$. Non-significant regional variables and distance to big cities have been dropped.

* Denotes coefficients significant at the $1 \%$ level.

** Denotes coefficients significant at the $5 \%$ level.

*** Denotes coefficients significant at the $10 \%$ level.

Eq. (5) is tested using two sets of data: first, using pooled cross-section data (Eq. (5a)), with a 1year lag between height and per capita income, the variation of stature and income over 5 years (thus $a=5, b=1$ and $c=6$ ), and a time dummy for the first period; second, using cross-section data (Eq. (5b)) with a 1-year lag and the variation of stature and income over 10 years $(a=10$, $b=1$ and $c=11)$.

As expected, the estimation results for Eq. (5), presented in Table 7, show a positive and significant coefficient for the growth rate of per capita income. An increase in income implies a rise in the consumption of high quality food, particularly proteins, ${ }^{43}$ and also a rise in health expenditures; both are likely to have a positive influence on stature. The coefficients for the variation in the number of midwives were not significant: the absolute number of midwives is the decisive variable. Regional dummy variables turned out to be significant and positive for Okinawa, but significant and negative for Tohoku, indicating that the northeast of Japan was badly hit by the economic recession of the early 1930s, which is consistent with narratives on living conditions in rural areas of northern Japan during the Great Depression.

\section{Convergence and divergence in biological welfare: evidence and interpretation}

This section uses body height data for identifying the patterns of $\sigma$ and $\beta$ regional convergence as well as personal convergence for Japan as a whole before WWII, measured as the coefficient of variation in stature. The concepts of $\sigma$ and $\beta$ regional convergence used here are the same as in Barro and Sala-I-Martin (1992), but height is used instead of per capita income. ${ }^{44} \sigma$ Convergence is measured as the unweighted coefficient of variation (standard deviation/average). $\beta$ Convergence is

\footnotetext{
${ }^{43}$ Per capita intake of animal protein increased markedly during the interwar period, according to governmental surveys quoted in Toyo Keizai, 1980, vol. 2, pp. 245-248; the original source is Sôrifu Tôkeikyoku, "Kouri Bukka Tôkei Chôsa" \{Cabinet Office, Statistics Bureau "Retail price data survey"\}.

${ }^{44}$ It should be noted that by relying upon body height, one escapes the problems related to purchasing power parity. Barro and Sala-I-Martin (1992) assume that differences in regional-level consumer price indices are negligible, which is untrue for Japan, especially during the 1950s.
} 
the process of catch-up of the poorest areas toward the level of the most affluent regions. ${ }^{45}$ It is measured here as the relation between the growth rate of height during the period investigated and the initial level (Eq. (6)).

$$
\frac{1}{T} \ln \left(\frac{H_{i, t}}{H_{i, t-T}}\right)=\alpha+\left[\ln \left(H_{i, t-\tau}\right)\right]\left(1-e^{\beta T}\right)\left(\frac{1}{T}\right)+D_{i}+\varepsilon
$$

where $H_{i, t-\tau}$ is the average height in prefecture $i$ at the beginning of the interval, $T$ is the length of the interval, and $D_{i}$ are regional dummy variables.

Personal inequality at the national level is measured as the coefficient of variation of height. ${ }^{46}$ The formula used for calculating yearly series of the coefficient of variation of height at the national level is the following:

$$
\mathrm{CV}_{t}=\sqrt{\sum_{i=1}^{n} N_{i t}\left(\frac{H_{i}}{H_{m t}}-1\right)^{2}}
$$

where $\mathrm{CV}_{t}$ is the coefficient of variation of height at time $t, N_{i t}$ is the share at time $t$ of the cohort of conscripts whose height was within the interval $i, H_{i}$ is the median height of interval $i$, and $H_{m t}$ is the average height of the cohort at time $t$. As data are missing for Okinawa before 1898 , this prefecture is excluded from the calculation of the CVi. The pattern of $\sigma$ regional convergence between 1895 and 1940, which is presented in Fig. 1, is characterized by a declining trend of the CV until WWI, indicating a convergence in biological welfare, and thereafter by fluctuation.

We should note the volatility of the CV of prefecture-level average height. One possible explanation of such large yearly variations are asymmetric shocks in which epidemic disease and/or crop failure leading to a deterioration in gross nutritional status (i.e., food shortages or malnutrition) affect different regions to a different extent. As prefecture-level yearly estimates of exposure to disease and nutritional intake are not available for the pre-WWII period, it is impossible to analyze the causes of yearly variations in height. In order to reduce the short-term volatility, which is presumably due to natural hazards that induced variation in food supply and relative prices of foodstuffs, the $\mathrm{CV}$ is also calculated on the basis of the 3-year moving average of prefecture-level height (Fig. 1). A clear trend of $\sigma$ convergence is observed until 1910, followed by divergence during the 1910s, convergence during the 1920s, and divergence again during the 1930s. ${ }^{47}$ The CV of personal inequality in height for Japan as a whole follows a steady

\footnotetext{
45 There is no space here to consider the problems related to the concept of $\beta$ convergence. See, for instance, Epstein et al. (2003) for a presentation of alternative methods. Also due to space limitations, no attempt has been made to use alternative methods. The major reason for using the same concepts of convergence as Barro and Sala-I-Martin (1992) is that one of the main purposes of this study is to compare their results relying on per capita income with those obtained when using regional series of height.

46 The measure of personal convergence is therefore comparable to that of regional $\sigma$ convergence. The use of the coefficient of variation is justified on the ground that, in contrast with the Gini coefficient or the Theil index, it is not biased by the growth in stature (Baten, 2000; Baten and Frauholz, 2004).

47 The same pattern is observed when plotting the CV only for the years 0 and 5, as in Barro and Sala-I-Martin (1992), to investigate regional inequality between 1892 and 1941. It should be noted that other prefecture-level series, for instance per capita income in Japanese cities (1953-88) and income per agricultural household (1930-37), exhibit a volatility comparable to the one observed in average height series.
} 


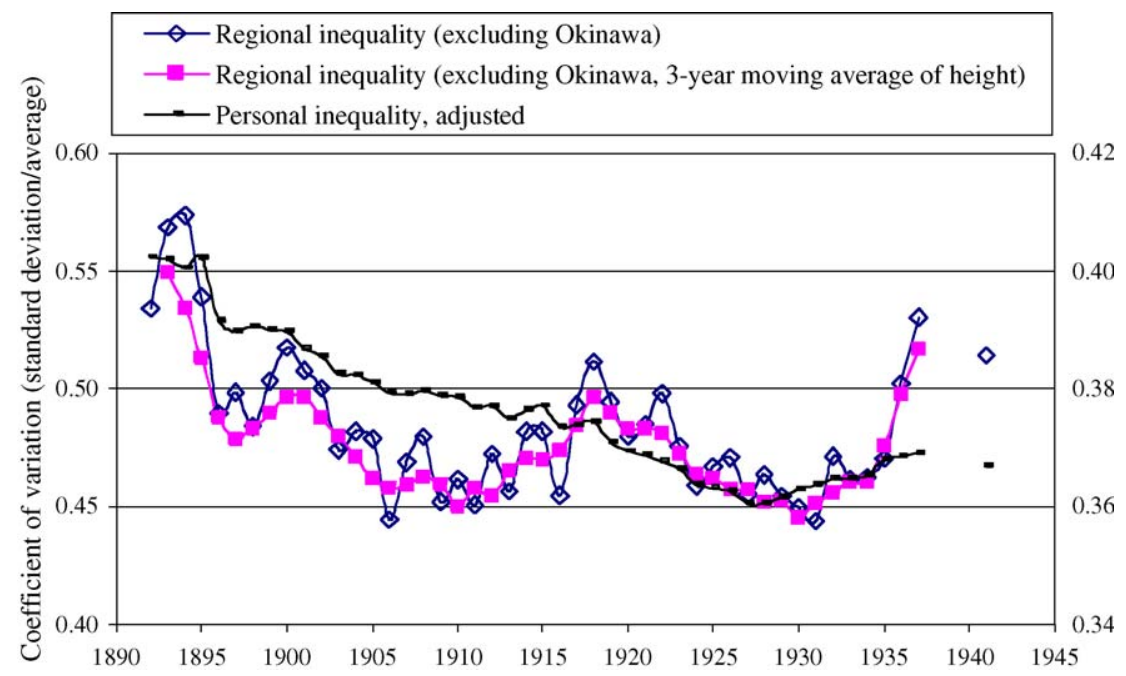

Fig. 1. Regional inequality ( $\sigma$ convergence) and personal inequality in average height, 1892-1941.

declining trend until the 1920s. As for the CV of regional inequality, an upward trend is observed during the 1930 s. $^{48}$

Table 8 reports the measure of $\beta$ regional convergence for 1893-1941 and for different sub-periods (see also Figs. 2 and 3). ${ }^{49}$ The starting years of the different sub-periods witnessed durable changes in the economic conditions. The year 1903 preceded the RussoJapanese War, which induced a boom in manufacturing output; 1913 is the last year before WWI, during which a surge of import substitution of consumer and capital goods occurred; 1930 marks the start of the rapid development of heavy industry triggered by military expenditures. A regional convergence is observed for the period 1893-1941 as prefectures with the lowest initial height showed a tendency to catch up (implied $\beta$-values are calculated on the basis of Eq. (6)). However, the implied $\beta$ shows that most of the convergence occurred before 1914, and these results are robust to the exclusion of regional dummies; implied $\beta$ values are in the range between 0.02 and 0.03 during the period 1893-1913. It seems that the trend of $\beta$ convergence persisted until World War II, but the $R$-square and the $\beta$ coefficients are close to 0.00 after 1913, and the results are significant only for certain specification of the equation.

For the 1930s, both height data and per capita income are available, so that it is possible to compare the convergence estimates using these two indicators. Barro and Sala-I-Martin (1992)

\footnotetext{
${ }^{48}$ It should be noted that there are two discontinuities in the series due to changes in measurement in 1928 (the shift to the metric system in the conscription stature data, see Appendix A for details) and then a reduction in the number of intervals in 1934. For the period 1928-1941, the yearly series are adjusted assuming that the coefficients of variation (CV) in 1928 and 1934 were the same as in the preceding year. As yearly fluctuations in the CV for the period before 1928 as well as in the 1928-1933 and 1934-1937 periods are rather small, this procedure seems acceptable, especially because the focus is on the trend rather than absolute levels.

491893 is used because Hokkaido data are not available for 1892; Okinawa, for which data are unavailable before 1898, is included in the sample from the period 1903-1913 onward.
} 
Table 8

Regressions for $\beta$ convergence of stature across Japanese prefectures (dependent variable: average height of conscripts)

\begin{tabular}{|c|c|c|c|c|}
\hline Period & & $\begin{array}{l}\text { Without } \\
\text { dummy variables }\end{array}$ & $\begin{array}{l}\text { Urban and Silk } \\
\text { dummy variables }\end{array}$ & $\begin{array}{l}\text { With regional } \\
\text { dummy variables }\end{array}$ \\
\hline 1893-1941 & $\begin{array}{l}\text { ln }(H) \\
t \text {-Stat } \\
\text { Implied } \beta \\
\text { Adjusted } R^{2}\end{array}$ & $\begin{array}{c}-0.87^{*} \\
-6.50 \\
0.013 \\
0.48\end{array}$ & $\begin{array}{c}-0.88^{*} \\
-7.57 \\
0.012 \\
0.62\end{array}$ & $\begin{array}{c}-0.80^{*} \\
-7.57 \\
0.013 \\
0.78\end{array}$ \\
\hline 1893-1913 & $\begin{array}{l}\ln (H) \\
t \text {-Stat } \\
\text { Implied } \beta \\
\text { Adjusted } R^{2}\end{array}$ & $\begin{array}{c}-0.56^{*} \\
-5.51 \\
0.022 \\
0.39\end{array}$ & $\begin{array}{c}-0.56^{*} \\
-6.66 \\
0.019 \\
0.58\end{array}$ & $\begin{array}{c}-0.47^{*} \\
-4.97 \\
0.022 \\
0.62\end{array}$ \\
\hline 1893-1903 & $\begin{array}{l}\ln (H) \\
t \text {-Stat } \\
\text { Implied } \beta \\
\text { Adjusted } R^{2}\end{array}$ & $\begin{array}{c}-0.39^{*} \\
-4.29 \\
0.033 \\
0.28\end{array}$ & $\begin{array}{c}-0.41^{*} \\
-5.06 \\
0.029 \\
0.44\end{array}$ & $\begin{array}{c}-0.34^{*} \\
-4.06 \\
0.034 \\
0.57\end{array}$ \\
\hline 1903-1913 & $\begin{array}{l}\ln (H) \\
t \text {-Stat } \\
\text { Implied } \beta \\
\text { Adjusted } R^{2}\end{array}$ & $\begin{array}{c}-0.24^{*} \\
-4.70 \\
0.022 \\
0.31\end{array}$ & $\begin{array}{c}-0.28^{*} \\
-5.67 \\
0.021 \\
0.44\end{array}$ & $\begin{array}{r}-0.23^{*} \\
-5.04 \\
0.02 \\
0.51\end{array}$ \\
\hline 1913-1941 & $\begin{array}{l}\ln (H) \\
t \text {-Stat } \\
\text { Implied } \beta \\
\text { Adjusted } R^{2}\end{array}$ & $\begin{array}{c}-0.10 \\
-1.28 \\
0.003 \\
0.01\end{array}$ & $\begin{array}{l}-0.14^{\text {**** }} \\
-1.83 \\
0.009 \\
0.10\end{array}$ & $\begin{array}{c}-0.27^{* *} \\
-4.35 \\
0.005 \\
0.58\end{array}$ \\
\hline 1913-1930 & $\begin{array}{l}\ln (H) \\
t \text {-Stat } \\
\text { Implied } \beta \\
\text { Adjusted } R^{2}\end{array}$ & $\begin{array}{c}-0.03 \\
-0.59 \\
0.002 \\
-0.0145\end{array}$ & $\begin{array}{c}-0.04 \\
-0.63 \\
0.012 \\
-0.00\end{array}$ & $\begin{array}{c}-0.22^{*} \\
-3.67 \\
0.002 \\
0.51\end{array}$ \\
\hline 1930-1941 & $\begin{array}{l}\ln (H) \\
t \text {-Stat } \\
\text { Implied } \beta \\
\text { Adjusted } R^{2}\end{array}$ & $\begin{array}{l}-0.05124 \\
-0.98 \\
0.005 \\
-0.0008\end{array}$ & $\begin{array}{l}-0.11^{* * * *} \\
2.00 \\
0.000 \\
0.10\end{array}$ & $\begin{array}{l}0.00 \\
0.01 \\
0.009 \\
0.38\end{array}$ \\
\hline
\end{tabular}

Notes: Non-significant dummy variables have been dropped.

* Denotes coefficients significant at the $1 \%$ level.

*** Denotes coefficients significant at the $5 \%$ level.

*** Denotes coefficients significant at the $10 \%$ level.

observe that the dispersion of income across prefectures increased during this period ( $\sigma$ divergence). However, they do not estimate $\beta$ coefficients for 1930-1940. The calculation is possible assuming, as these authors did, that regional differences in price variations are negligible. Thus, the GDE deflator for Japan as a whole can be used as a proxy for all the prefectures in order to convert figures in current yen into constant yen. Table 9 reports the results of the regression analysis for per capita income. The negative sign and significance of the implied $\beta$ coefficient indicates that a divergence occurred during the 1930s. This may be due to the lag in the impact of per capita income upon biological welfare. As conscription height data are not available after 1941, we cannot verify this possible explanation. Another possibility is that the divergence in per capita income found here results from an underestimation of purchasing power in rural prefectures in 1940 because of the assumption of no regional differences in inflation. 
Table 9

Regressions for $\beta$ convergence in per capita income across Japanese prefectures (dependent variable: per capita income at constant prices)

\begin{tabular}{llcc}
\hline Period & & Without dummy variables & With regional dummy variables \\
\hline $1930-1940$ & Standard error & 0.20 & 0.17 \\
& $\ln (H)$ & 0.25 & 0.21 \\
& $t$-Stat & 4.01 & 3.44 \\
& Implied $\beta$ & -0.029 & -0.024 \\
& Adjusted $R^{2}$ & 0.25 & 0.49 \\
\hline
\end{tabular}

Notes: Non-significant dummy variables have been dropped.

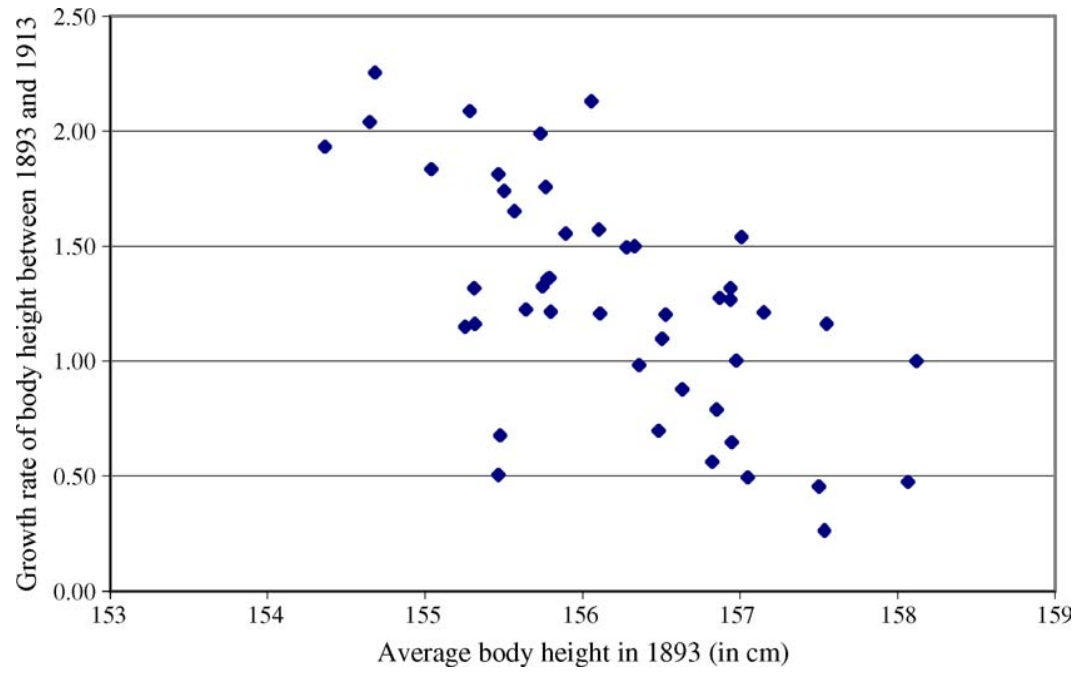

Fig. 2. $\beta$ Convergence across the 47 Japanese prefectures, 1893-1913.

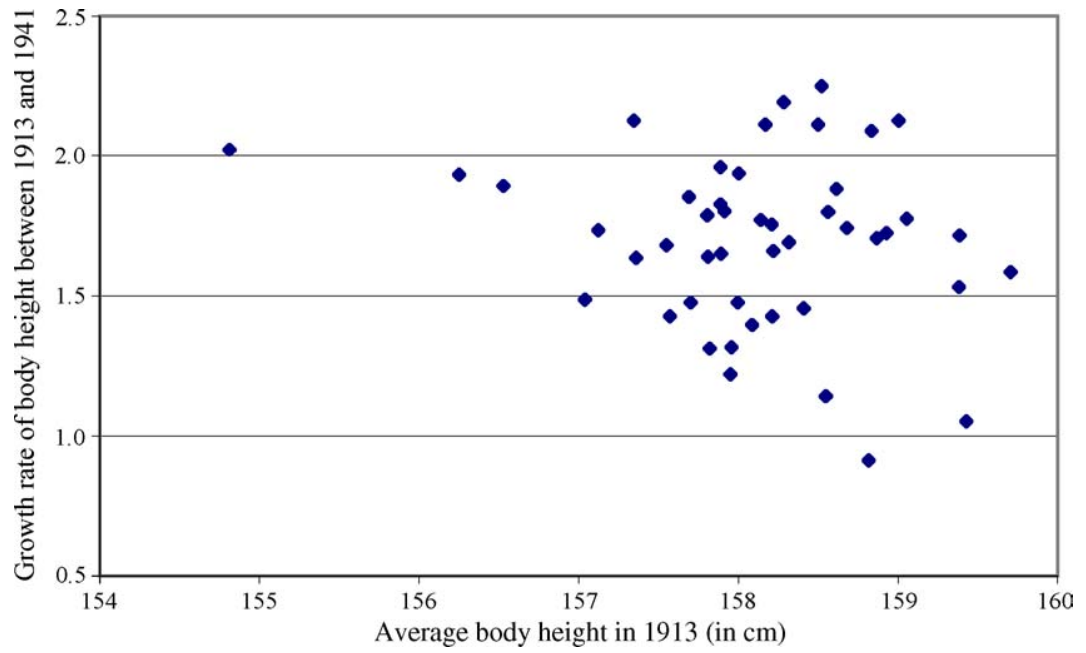

Fig. 3. $\beta$ Convergence across the 47 Japanese prefectures, 1913-1941. 
How can we explain the regional convergence in biological welfare that occurred before 1914 ? Although part of the story certainly lies in public health policy, ${ }^{50}$ it is likely that the integration of the national market brought by the reduction of transportation costs played a major role. Before the development of the railway network in the late 19th and early 20th century, the high cost of inland transportation limited the specialization of the different regions and the shipment of grains to areas suffering from crop failure. As yearly volatility and regional differences in the price of staple foodstuffs declined sharply during the late 19th century, it is likely that the risk of exposure to periodic shortages of food was reduced. This may be the main explanation of the rapid pace of $\sigma$ convergence among the regions of western Japan in the late 19th century.

The reduction in transportation costs also allowed the most remote regions to improve the allocation of factors by reducing the share of acreage under cultivation of grain crops, such as barley, millet, or buckwheat, which yielded a lower net income than rice. Non-rice grains accounted for about half of the output of staple in early Meiji Japan, ${ }^{51}$ and their cultivation reduced the risk of a sharp decline in local food supply. Similarly, lower transportation costs allowed several prefectures to enhance their specialization in silk production. Silk producers relied increasingly on rice produced in other areas and were therefore able to increase the share of the acreage under mulberry cultivation. Thus, Smithian growth resulting from the integration of the national economy induced a catch-up of the predominantly rural prefectures that became suppliers of food and non-food items for the growing populations of the urban areas. This could be also the origin of the contraction in personal inequality in biological welfare for Japan as a whole.

The slowdown of $\sigma$ and $\beta$ convergence after 1910 can be interpreted in two complementary ways. First, the end of convergence could be the consequence of the opening of the domestic food market to imports of soybeans from Korea and Northern China, particularly after 1905, and rice from the Japanese colonies after WWI. The decline in the relative price of staple foodstuffs certainly contributed to an improvement in the welfare of poor residents in urban areas. Yet, as most of the poorest rural prefectures had a rice surplus, it is likely that their residents suffered from the decline in the price of foodstuffs relative to other goods, and were therefore the losers in this process, at least in terms of relative level of welfare, in comparison with the Japanese average. Second, another possible explanation of the $\sigma$ divergence observed during the 1910s is the growth of the manufacturing sector during the Russo-Japanese war and WWI which induced a rise in incomes that was more rapid in urban than in rural areas. In this case, the $\sigma$ convergence observed immediately after WWI (Fig. 1) would then be explained by the slowdown in the growth of manufacturing output and the contraction in the gap between urban industrial wages

\footnotetext{
${ }^{50}$ Investigating in detail the role of this variable would require the construction of prefecture-level estimates of healthrelated public expenditure. It is likely that several institutional changes contributed to the improvement of health conditions in urban areas such as the Factory Law (Kôjô Hô) of 1911, implemented in 1916; the National Health Insurance Act (Kokumin Kenkô Hoken Hô) of 1922, implemented in 1927, but covering exclusively mining and manufacturing workers. Rural areas were covered only after the extension of health insurance to other workers as a result of a law adopted in 1938. In addition, one should mention the Local Improvement Movement (Chihô Kairyô Undô) introduced in 1906 (Pyle, 1973). Although not focused on public health policy, this movement certainly enhanced the role of traditional forms of social policy at the village level that had existed since the early modern period (such as occasional food distributions to villagers by landlords and village heads during festivals and other forms of income redistribution); the fact that medical care penetrated gradually into rural areas probably contributed to increases in regional inequality in biological welfare during the interwar period. The Law on the Physical Strength of the Population (Kokumin Tairyoku Hô) of 1940 seems to mark the start of a comprehensive national coverage of public health policy, including all rural areas. For an account of the history of social policy in Japan, see Ikeda (1986).

${ }^{51}$ National average (Umemura et al., 1983, pp. 33-49); the figure was much higher in the mountainous areas.
} 
and rural farming wages for males. ${ }^{52}$ The continuing increase in personal equality until the mid1920s nevertheless appears consistent with the continuing regional convergence in biological welfare. Agricultural producers lost out, while the lowest segments of the rural and urban population, whose income consisted largely of wages, benefited from the strong demand for labor during World War I and the low relative prices of foodstuffs during the early 1920s. The rapid pace of industrialization during the 1930s, and the collapse of the relative price of agricultural products, particularly silk, helped to amplify further the gap between the core urban regions and the poorest rural areas.

\section{Summary and conclusion}

Relying on a new database of regional time series of height of 20 -year-old conscripts, information on per capita income, and other indicators of standards of living, this paper investigates the relationship between income, health, and stature, and analyzed changes in regional inequality in Japan between the 1892 and 1941. The main findings can be summarized as follows: first, there was a high correlation between income and stature before World War II; second, regional income inequality explains variations in the ranking of prefectures in terms of biological welfare during the 1930s; third, regional convergence in biological welfare occurred before World War I; fourth, the dispersion in regional income increased during the 1930s; fifth, the pattern is similar for personal inequality in biological welfare at the national level.

The evidence of a high correlation between stature and per capita income obtained when using cross-section analysis opens up avenues for further research on the long-term relationship between income distribution and economic growth. Personal inequality could be measured by relying on height distribution in each prefecture and introduced in the analysis as an additional explanatory variable. Because there is not much problem in terms of sample bias in the stature data for male and female students collected by the Ministry of Education after WWII, it is possible linking pre-WWII conscription data with post WWII data of the Ministry of Education for analyzing the secular trend at the prefecture-level from the late 19th century to the present. In addition, post WWII stature data could be used in order to investigate if a correlation is observed between per capita income and stature at the cross-sectional prefecturelevel during the Japan's High Speed Growth (during the 1950s and 1960s), and if it still exists in the recent period.

\section{Acknowledgments}

This research has been undertaken under a Maison-Franco Japonaise scholarship as Visiting Research Fellow at the Institute of Economic Research, Hitotsubashi University, Tokyo. I am grateful to the French Ministry of Foreign Affairs for financial support, to the Institute of Economic Research, Hitotsubashi University for hospitality, and to Joerg Baten, John Komlos, Debin Ma, Carl Mosk, Osamu Saito, Bernard Thomann, Ken-ichi Tomobe, and the participants in research seminars at the Keio University and Oxford University for helpful comments and suggestions.

\footnotetext{
${ }^{52}$ See (Ohkawa and Shinohara, 1979, 113) regarding manufacturing output, and Ohkawa et al. (1967) on rural and urban wages.
} 


\section{Appendix A. Data sources and estimation procedures}

The original sources for the height of conscripts are Rikugunshô Tokei Nenpô [Statistical Yearbook of the Imperial Army], Nippon Teikoku Tôkei Nenpô [Statistical Yearbook of the Empire of Japan] and Nippon Rikugun Chôhei Tekiyô [Report on the Conscription of the Japanese Army]. These official yearly reports do not provide data for the average height of the conscripts originating from each region (except for the last years). These averages can be calculated by relying on the number of conscripts for each interval of body height. For instance, in the report for the year 1941, the interval is of $5 \mathrm{~cm}$ with open tails below $140 \mathrm{~cm}$ and above $180 \mathrm{~cm}$. The percentage of conscript for which the information is reported as missing is extremely low ( $0.7 \%$ in 1926, $0.9 \%$ in 1927, and 0.6\% in 1928-1932 and 1941; no information is available for other years). Data are in Japanese measure, shaku and sun ( 30.3 and $3.03 \mathrm{~cm}$, respectively) between 1892 and 1927 and in centimeters thereafter. The average is calculated for each prefecture using the median value of each interval. For the upper and lower open tails, it is assumed that the difference between the median value of the open tail and the median value of the closest interval is equal to the difference between the medians of adjacent intervals. Because the number of conscripts in the open tails and the intervals close to these open tails is small, this approximation is unlikely to impact on the values of average heights. What is more, the calculation yields exactly the same results as the data on average body height for Japan as a whole and for each prefecture when this information is provided in official sources (such as in 1941). Before 1898, regional conscription data are for the traditional administrative units, the kuni (literally "country", but it could be translated as province). The conversion of data for kuni to prefectures (fudôken) is based on a comparison of administrative maps. In most cases, the prefecture is equivalent to one or two provinces.

The number of midwives is reported in Dainippon Teikoku Naimushô Tôkei Hôkoku [Statistical Report of the Ministry of Interior, Empire of Japan]. Data are available for the period 1884-1935 (data for the year 1921 are missing, while the data for 1908 are implausibly low). There is a discontinuity in the series in 1899. Until that date, some midwives only had local permits, while others had a national permit granted by the Ministry of Interior. From 1900, midwives were under the control of the Ministry of Interior. This institutional change led to a sharp reduction in the number of midwives recorded.

Prefecture-level total population data from 1884 onwards are obtained from the CD-ROM Historical Statistics of Japan (1868-1985) edited by the Statistics Bureau, Management and Coordination Agency and published in 1999 by the Japan Statistical Association. Missing data for 1885-87, 1889-92, 1894-97, 1899-1902, 1904-07, 1909-12, 1914-17, and 1919 have been interpolated. Prefecture-level yearly series of the average height of conscripts and the number of midwives are available upon request in electronic format.

\section{Appendix B. List of administrative regions and list of prefectures for each region}

The regions are groups of prefectures as defined in conscription data: Tohoku, Kanto, Hokuriku, Tosan, Tokai, Kinki, Chugoku, Shikoku, and Kyushu. The island of Hokkaido and the southern archipelago of Okinawa prefecture are two separate regions. The prefectures belonging to the different regions are as follows:

(1) Tohoku (6 prefectures): Akita, Aomori, Fukushima, Iwate, Miyagi, and Yamagata.

(2) Kanto (7 prefectures): Chiba, Ibaraki, Gunma, Kanagawa, Saitama, Tokyo, and Tochigi.

(3) Hokuriku (4 prefectures): Fukui, Ishikawa, Niigata, and Toyama. 
(4) Tosan (3 prefectures): Gifu, Nagano, and Yamanashi.

(5) Tokai (3 prefectures): Aichi, Mie, and Shizuoka.

(6) Kinki (6 prefectures): Hyogo, Kyoto, Nara, Osaka, Shiga, and Wakayama.

(7) Chugoku (5 prefectures): Hiroshima, Okayama, Shimane, Tottori, and Yamaguchi.

(8) Shikoku (4 prefectures): Ehime, Kagawa, Kochi, and Tokushima.

(9) Kyushu (7 prefectures): Fukuoka, Kagoshima, Kumamoto, Miyazaki, Nagasaki, Oita, and Saga.

(10) Hokkaido (1 prefecture).

(11) Okinawa (1 prefecture).

Appendix C. Map of Japan (47 prefectures)

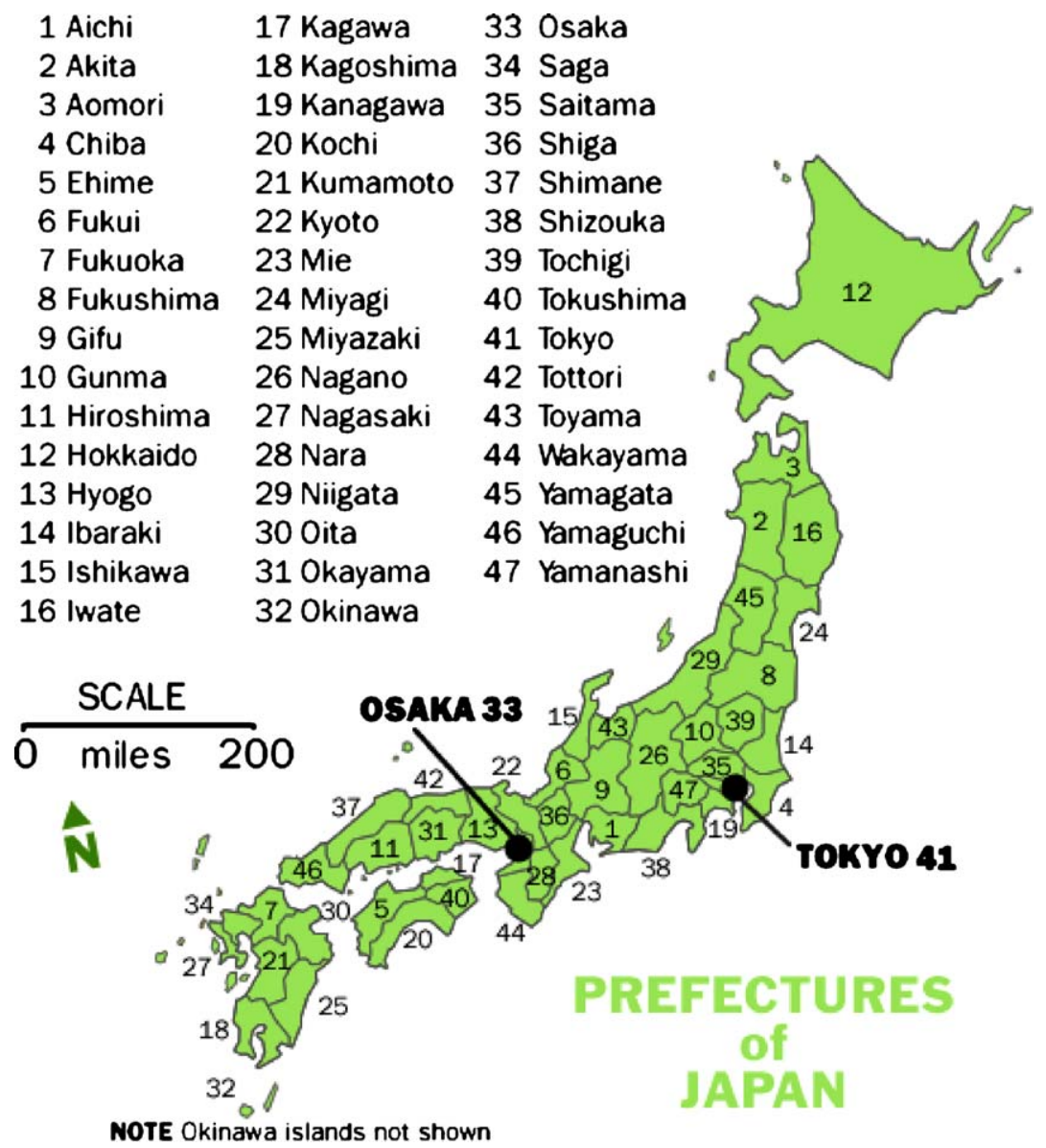




\section{References}

Barro, R.J., Sala-I-Martin, X., 1992. Regional growth and migration: A Japan-United States comparison. J. Jpn. Int. Econ. 6, 312-346.

Bassino, J.-P., 2006. The growth of agricultural output and food supply in Meiji Japan: economic miracle or statistical artifact? Econ. Dev. Cult. Change 54, in press.

Baten, J., 2000. Economic development and the distribution of nutritional resources in Bavaria, 1797-1839. J. Income Distribution 9, 89-106.

Baten, J., 2001. Heights and real wages in the 18th and 19th centuries: an international overview. Jahrbuch fuer Wirtschaftsgeschichte 1, 17-32.

Baten, J., Frauholz, U., 2004. Did partial globalization increase inequality? Did inequality stimulate globalization backlash? The case of the Latin American periphery, 1950-2000. CESifo Econ. Stud. 50, 45-81.

Baten, J., Murray, J.E., 2000. Heights of men and women in nineteenth century Bavaria: economic, nutritional, and disease influences. Explor. Econ. Hist. 37, 351-369.

Bourguigon, F., Morrison, C., 2002. Inequality among world citizens: 1820-1992. Am. Econ. Rev. 92, 727-744.

Brinkman, H.J., Drukker, J.W., Slot, B., 1988. Height and income: a new method for the estimation of historical national income series. Explor. Econ. Hist. 25, 227-264.

Cole, T.J., 2003. The secular trend in human physical growth: a biological view. Econ. Hum. Biol. 1, 161-168.

Dainippon Teikoku Naimushô, [Ministry of Interior, Empire of Japan], 1884-1935. Dainippon Teikoku Naimushô Tôkei Hôkoku [Statistical Report of the Ministry of Interior, Empire of Japan]. (Naimushô [Ministry of Interior], Tokyo).

Dunn, F.L., 1993. Malaria. In: Pyle, K. (Ed.), Cambridge World History of Human Disease. Cambridge University Press, Cambridge, pp. 855-863.

Epstein, P., Howlett, P., Schultze, M.-S., 2003. Distribution dynamics: stratification, polarization and convergence among OECD economies, 1870-1992. Explor. Econ. Hist. 40, 78-93.

Honda, G., 1997. Differential structure, different health: industrialization in Japan, 1868-1940. In: Steckel, R.H., Floud, R. (Eds.), Health and Welfare During Industrialization. Chicago University Press, Chicago, pp. 251-284.

Igarashi E., Takahashi H., revised by H.E., Count, S., Okuma, with a preface by H.E., Baron, E., Shibuzawa, 1906. The National Wealth of Japan (The National Wealth of Japan Publication Office, Tokyo).

Ikeda, Y., 1986. Nihon Shakai Fukushishi [History of Japanese Social Policy]. Hôritsu Bunkasha, Tokyo.

Ishige, N., 2000. Japan. In: Kiple, K.F., Ornelas, K.C. (Eds.), Cambridge History of Food, 1. Cambridge University Press, Cambridge, pp. 1175-1182.

Johannson, S.R., Mosk, C., 1987. Exposure, resistance and life expectancy: disease and death during the economic development of Japan. Popul. Stud. 41, 207-235.

Kato, Y., 1996. Chôheisei to Kindai Nihon 1868-1945 [Conscription in Modern Japan, 1868-1945]. Yoshikawa Kobun Kan, Tokyo.

Kenny, C., 2005. Why are we worried about income? Nearly everything that matters is converging. World Dev. 33, 1-19.

Komlos, J., 1985. Stature and nutrition in the Habsburg monarchy: the standard of living and economic development in the eighteenth century. Am. Hist. Rev. 90 (5), 1149-1161.

Komlos, J., 1989. Nutrition and Economic Development in the Eighteenth-Century Habsburg monarchy: An Anthropometric History. Princeton University Press, Princeton, NJ.

Komlos, J., 1993. Stature and health. In: Pyle, K. (Ed.), World History of Human Disease. Cambridge, pp. $238-243$.

Komlos, J., 1998. Shrinking in a growing economy: the mystery of physical stature during the Industrial Revolution. J. Econ. Hist. 58 (3), 779-802.

Kuznets, S., 1955. Economic growth and income inequality. Am. Econ. Rev. 45, 1-28.

Mandemakers, C.A., van Zanden, J.L., 1993. The height of conscripts and national income: apparent relations and misconceptions. Explor. Econ. Hist. 30, 81-97.

Margo, R., Steckel, R.H., 1983. Heights of native born whites during the antebellum period. J. Econ. Hist. 43, $167-174$.

Mazza, G., 2000. Buckwheat. In: Kiple, K.F., Ornelas, K.C. (Eds.), Cambridge History of Food, vol. 1. Cambridge University Press, Cambridge, pp. 90-97.

Meisel, A. Vega, M., 2004. A tropical success story: a century of improvements in the biological standard of living, Columbia 1910-2002. Paper presented at the Fifth World Congress of Cliometrics (Venice, 8-11 July; http:// www.banrep.gov.co/docum/ftp/borra289.pdf).

Minami, R., 1995. Income inequality in the economic development of Japan: an evaluation of the Kuznets hypothesis. Hitotsubashi University, Institute of Economic Research, Discussion Paper Series B19. 
Moriguchi, C., Saez, E., 2004. The evolution of income concentration in Japan, 1885-2002: evidence from income tax statistics. Paper presented at the 2004 Economic History Association Meeting.

Mosk, C., 1996. Making Health Work: Human Growth in Modern Japan. University of California Press, Berkeley.

Mosk, C., Johannson, S.R., 1986. Income and mortality: evidence from modern Japan. Popul. Dev. Rev. 12, 415-440.

Mosk, C., Pak S., 1978. Food Consumption, Physical Characteristics, and Population Growth in Japan, 1874-1940. Working Paper No 102, University of California, Berkeley, Department of Economics.

NHK, 1990. Kokumin Seikatsu Jikan Chôsa 1990 [National Survey on Time Allocation in 1990]. NHK Hoso Bunka kenkyujo, Tokyo.

NHK, 2000. Kokumin Seikatsu Jikan Chôsa 1990 [National Survey on Time Allocation in 2000]. NHK Hoso Bunka Kenkyujo, Tokyo.

Nippon Rikugun [Japanese Army], 1941. Nippon Rikugun Chôhei Tekiyô [Report on the Conscription of the Japanese Army]. Nippon Rikugun [Japanese Army], Tokyo.

Nippon Teikoku Tôkei Nenkan, 1882-1940. [Statistical Yearbook of the Empire of Japan], 1895-1936. Naikaku Tokei Kyokai [Cabinet Office Statistical Association], Tokyo.

O’Rourke, K.H., Williamson, J.G., 1999. Globalization and History: The Evolution of a Nineteenth Century Atlantic Economy. MIT Press, Cambridge, Mass.

Obi, K., Nishikawa, S., 1961. Obo hoteishiki ni yoru rôdô shijô no bunseki [An analysis of labor market and regional mobility] Keizaigaku Nenpo, 4. Keio University, pp. 177-268.

Oe, S., 1981. Chôheisei [The Conscription System]. Iwanami, Tokyo.

Olds, K.B., 2003. The biological standard of living in Taiwan under Japanese occupation. Econ. Hum. Biol. 1, $187-206$.

Ohkawa, K., Noda, T., Takamatsu, N., Yamada, S., Kumazaki, M., Shionoya, Y., Minami, R., 1967. Bukka [Prices], Choki Keizai Tokei [Estimates of Long Term Economic Statistics], 6. Toyo Keizai, Tokyo.

Ohkawa, K., Shinohara, M. (Eds.), 1979. Patterns of Japanese Economic Development: A Quantitative Appraisal. Yale University Press, New Haven.

Pyle, K., 1973. The technology of Japanese nationalism: the local improvement movement, 1900-1918. J. Asian Stud. 33 (1), 51-65.

Rikugunshô [Ministry of the Imperial Army], 1892-1895 Rikugunshô Tokei Nenpô [Statistical Yearbook of the Imperial Army]. (Rikugunshô [Imperial Army], Tokyo).

Rokuhara, H., 2005. Local officials and the Meiji conscription campaign. Monumenta Nipponica 60 (1), 81-110.

Rosés, J.R., Sánchez-Alonso, B., 2004. Regional wage convergence in Spain 1850-1930. Explor. Econ. Hist. 41, $404-$ 425.

Saito, O., 2003. Taii no seichô to keizai hatten: Meijiki Yamanashi ken gakkô shinchô kiroku no bunseki [Human growth and economic development: an examination of school physical records, Yamanashi prefecture, Meiji Japan]. Econ. Res. Keizai Kenkyu 54 (1), 19-32.

Saito, O., 2004. Senzen Nihon ni okeru taii no kettei yoin: Tôhoku nôson no shinchô kensa kiroku bunseki [The determinants of height, weight and weight-for-height in prewar Japan; An analysis of conscription records for a northeastern village]. Econ. Res. Keizai Kenkyu 55 (3), 193-203.

Sandberg, L.G., Steckel, R.H., 1997. Is industrialization hazardous to your health? Not in Sweden. In: Steckel, R.H., Floud, R. (Eds.), Health and Welfare During Industrialization. Chicago University Press, Chicago, pp. 127-160.

Sato, K., 1997. Nihon no jôsanpu no kenkyû [Research on Japanese Midwives]. Higashiginza Shuppansha, Tokyo.

Sawayama, M., 1998. Shussan to Shintai no Kindai [A Modern History of Birth and Body Height]. Keiso Shobô, Tokyo.

Shay, T., 1994. The level of living in Japan, 1885-1938: New evidence. In: Komlos (Eds.), Stature, Living Standards, and Economic Development: Essays in Anthropometric History. The University of Chicago Press, Chicago, pp. 173201.

Shinohara, M., 1967. Kojin Shôhi Shûshutsu [Personal Consumption Expenditures] Chôki Keizai Tôkei [Estimates of Long Term Economic Statistics], 6. Tôyô Keizai, Tokyo.

Smethurst, R.J., 1974. A Social Basis for Prewar Militarism: The Army and the Rural Community. University of California Press, Berkeley.

Steckel, R.H., 1995. Stature and standard of living. J. Econ. Lit. 33, 1903-1940.

Steckel, R.H., 1999. Industrialization and health in historical perspective. NBER Working Paper No. H0118.

Taeuber, I., 1958. The Population of Japan. Princeton University Press, Princeton.

Tominaga, H., 2003. Senzen Okinawa no shotoku shisan [Income estimates for pre-World War II Okinawa]. Keizai Kenkyu (Ryukyu Daigaku), 63, special issue, March.

Toyo Keizai (Eds.), 1980. Shôwa Kokusei Sôran [Statistics of the Showa era]. Tôyô Keizai Shinpôsha, Tokyo.

Umemura, M., Takamatsu, N., Itoh, S. (Eds.), 1983. Chiiki Keizai Tôkei [Regional Economic Statistics], Chôki Keizai Tôkei [Estimates of Long Term Economic Statistics], 13. Toyo Keizai, Tokyo. 
Ushiroyama, T., Sakuma, K., Souen, H., Nakai, G., Morishima, S., Yasuda, K., Orino, I., Ueki, M., 2003. Therapeutic effects of Kyuki-chouketsu-in in restoring postpartum physical condition. Am. J. Chin. Med. 31, 437-444.

Weir, D., 19997. Economic welfare and physical well-being in France, 1750-1990. In: Steckel, R.H., Floud, R. (Eds.), Health and Welfare During Industrialization. Chicago University Press, Chicago, pp. 161-200.

Williamson, J.G., 1965. Regional inequality and the process of national development: a description of the patterns. Econ. Dev. Cult. Change 13-4 (part 2), 3-84.

Williamson, J.G., 2000. Globalization, factor prices and living standards in Asia before 1940-1550. In: Latham, A.J.H., Kawakatsu, H. (Eds.), Asia Pacific Dynamism. Routledge, London, pp. 13-45.

Williamson, J.G., 2002. Land, labor, and globalization in the Third World, 1870-1940. J. Econ. Hist. 62, 55-85. 